Andrews University

Digital Commons @ Andrews University

1997

\title{
A Strategy To Reach the English-Speaking People of the Bay Islands of Honduras
}

Stavely P. Elwin

Andrews University

Follow this and additional works at: https://digitalcommons.andrews.edu/dmin

Part of the Practical Theology Commons

\section{Recommended Citation}

Elwin, Stavely P., "A Strategy To Reach the English-Speaking People of the Bay Islands of Honduras" (1997). Professional Dissertations DMin. 571.

https://dx.doi.org/10.32597/dmin/571

https://digitalcommons.andrews.edu/dmin/571

This Project Report is brought to you for free and open access by the Graduate Research at Digital Commons @ Andrews University. It has been accepted for inclusion in Professional Dissertations DMin by an authorized administrator of Digital Commons @ Andrews University. For more information, please contact repository@andrews.edu. 


\section{ABSTRACT}

A STRATEGY TO REACH THE ENGLISH-SPEAKING

PEOPLE OF THE BAY ISLANDS

OF HONDURAS

by

Stavely Perry Elwin

Adviser: Bruce L. Bauer 


\title{
ABSTRACT OF GRADUATE STUDENT RESEARCH
}

Dissertation

\author{
Andrews University \\ Seventh-day Adventist Theological Seminary
}

Title: A STRATEGY TO REACH THE ENGLISH-SPEAKING PEOPLE OF THE BAY ISLANDS OF HONDURAS

Name of researcher: Stavely p. Elwin

Name and degree of faculty adviser: Bruce L. Bauer, D.Miss. Date completed: June 1997

\section{Problem}

The English-speaking Seventh-day Adventist church in the Bay Islands has experienced slow growth over the last ten years. An evaluation reveals that some of the problems include poor evangelistic methods, few well trained pastors and workers, the churches' lack of support from the local mission and pastors, and no material provisions for the departments of the church. In addition, programs are lacking to help members come in contact with secular-minded people, 
and the methods used to improve the retention rate of newly baptized members indicate there is a tremendous need for change in the style of evangelism in the English-speaking churches of the Bay Islands.

Method

This dissertation analyzes the introduction of Christianity in Honduras and how the Seventh-day Adventist church was planted in the Bay Islands. It seeks to develop methods and approaches which would be helpful for those who will be engaged in this ministry. In order to gain the necessary insights for an effective approach to church growth, a description of church growth as recorded in the biblical book of Acts is given.

\section{Results}

The results of the study indicated that the Bay Islands Mission did not take into consideration other options and new approaches to evangelism in their attempt to evangelize the English-speaking people of the Bay Islands. It was emphasized that contact programs are not only an effective vehicle for evangelism, but also provide situations in which the cooperative ministry of the laity and clergy come into contact with the people of the community, thereby, 
developing healthy relationships. These results call for new programs and methods to reach the English-speaking people of the Bay Islands.

\section{Conclusion}

It is important to remember that the programs presented in this project are only methods and should not be considered the only and absolute method. I am convinced, however, that if the Bay Islands Mission adopts the contact programs presented in this project it will cause church renewal, revitalization, and growth. This project concludes that if the Bay Islands English-speaking churches should experience any significant growth, the old methods of evangelism used to evangelized the English-speaking people must give way to new approaches. 


\title{
Andrews University
}

Seventh-day Adventist Theological Seminary

\section{A STRATEGY TO REACH THE ENGLISH-SPEAKING PEOPLE OF THE BAY ISLANDS OF HONDURAS}

\author{
A Dissertation \\ Presented in Partial Fulfillment \\ of the Requirements for the Degree \\ Doctor of Ministry
}

by

Stavely P. Elwin

June 1997 



\section{A STRATEGY TO REACH THE ENGLISH- SPEAKING PEOPLE OF THE BAY ISLANDS OF HONDURAS}

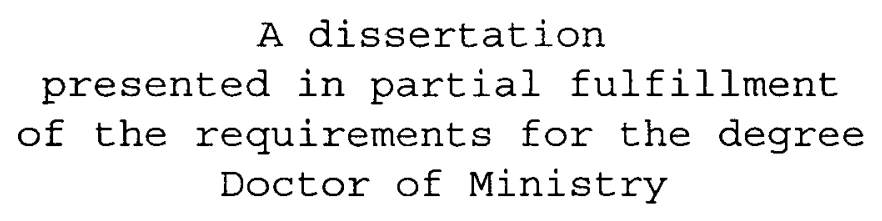

A dissertation presented in partial fulfillment of the requirements for the degree Doctor of Ministry

\section{by}

Stavely P. Elwin

APPROVAL BY THE COMMITTEE:

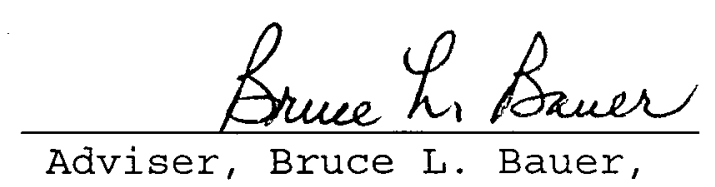

Adviser, Bruce L. Bauer,

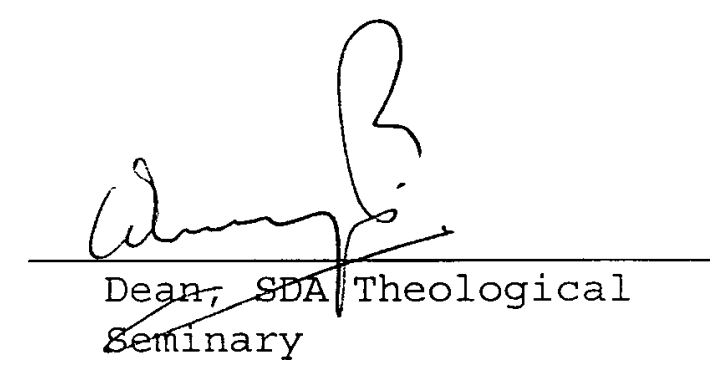

Seminary

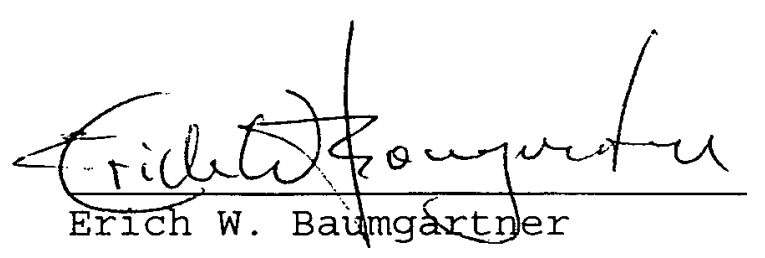

Prcado Chorton

Ricardo Norton

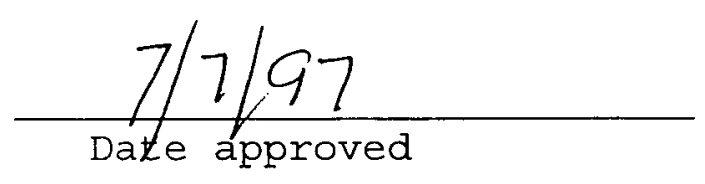


TABLE OF CONTENTS

ACKNOWLEDGMENTS ....................... vi

Chapter

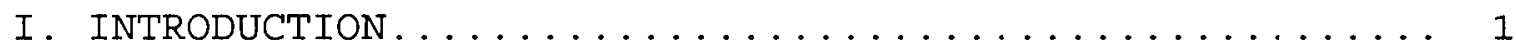

Statement of the Task................ 4

Justification for the Dissertation.......... 4

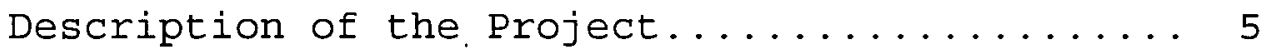

Definition of Terms.................... 7

II. A CULTURAL AND HISTORICAL BACKGROUND OF THE

BAY ISLANDS ......................... 8

Introduction.................... 8

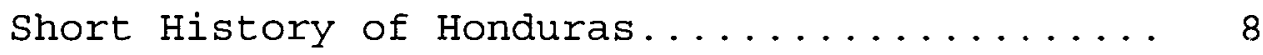

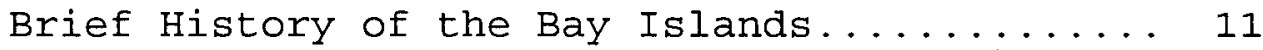

Protestantism and Missions in Honduras....... 13

Religious History of the Bay Islands.... 14

The Entrance of Protestantism in Honduras

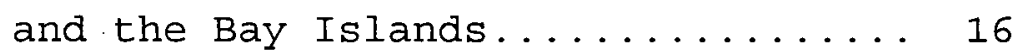

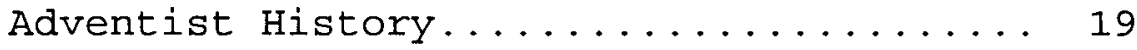

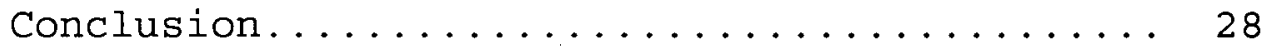

III. CHURCH-GROWTH THEOLOGY AND PRACTICE......... 30

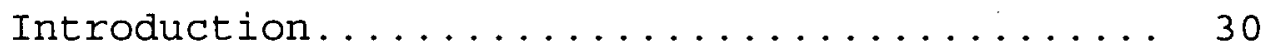

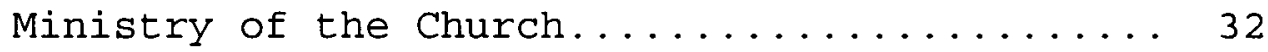

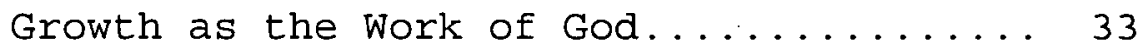

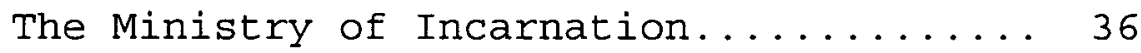

Holistic Ministry of the Church........ 39

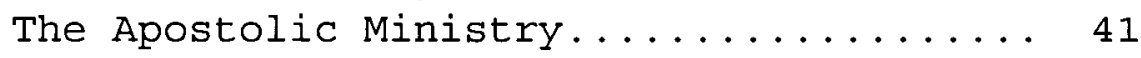

The Church: A Missionary Body............ 42

Growth Patterns..................... 44

Numerical Growth................ 44 
Qualitative Growth.............. 46

Church Organization.............. 48

Church Planting............... 50

Conclusion...................... 54

IV. A CHURCH GROWTH STUDY OF THE BAY

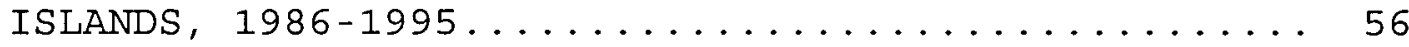

Introduction. .................. 56

Demographic Study of the Bay Islands

of Honduras................... 57

People of the Bay Islands.......... 60

Contextual Factors................ 60

Description of Church-Growth Patterns of the

Bay Islands.................. 62

Analysis of Growth Among the English-

Speaking Churches of the

Bay Islands...................... 72

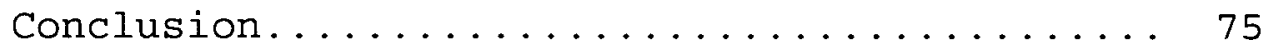

V. A STRATEGY TO REACH THE ENGLISH SPEAKERS

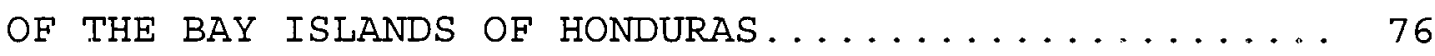

Introduction.................. 76

Points of Contact............... 78

Bay Islands Youth Outreach.......... 80

Peer Prevention Programs............ 81

IntraMural Programs.............. 83

Community Programs............... 84

Vacation Bible School (VBS) ......... 86

Contact Seminars................ 87

Attraction Seminar.............. 88

Bridge Seminars............... 89

Response Seminars............... 90

Doctrinal Seminars................ 91

Conclusion..................... 92

VI. SUMMARY, RECOMMENDATIONS, AND CONCLUSIONS........ 95

Summary ....................... 95

Recommendations................. 97

Conclusion..................... 101 


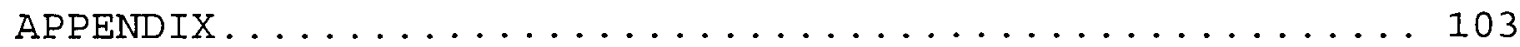

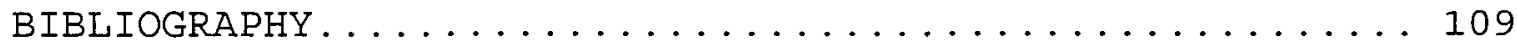

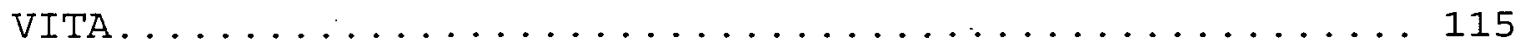




\section{LIST OF ILLUSTRATIONS}

1. Membership Per Year..................... 65

2. Number of Baptisms Per Year...............66

3. English Baptisms Per Year.................67

4. Spanish Baptisms Per Year................. 68

5. English and Spanish Annual Growth Rate (AGR) ....... 69

6. Comparison of Spanish and English Baptisms 1986-95... 70

\section{LIST OF TABLES}

1. Membership Growth of Both English and Spanish

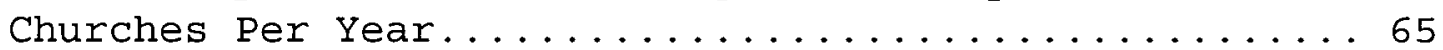

2. Number of Baptism Per Year For Bay Islands........66

3. English Baptisms Per Year.................6 67

4. Spanish Baptisms Per Year.................68

5. Percentage of AGR Per Year..................69

6. A Comparison of Spanish and English Baptisms

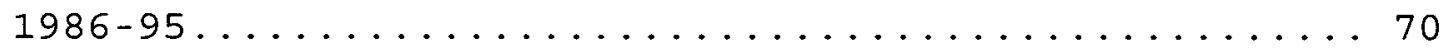


ACKNOWLEDGMENTS

First of all, I would like to record officially my gratitude to God for health, strength, and time without which this project would have been impossible.

Second, I would Iike to thank Dr. Bruce L. Bauer, Director of the Doctor of Ministry Program, and chairman of my dissertation committee, Dr. Erich W. Baumgartner, and Dr. Ricardo Norton, whose guidance and suggestions made this project a reality.

Special recognition needs to be given to my parents, Stavely and Fausta Elwin, for their encouragement and moral and financial support, for without them this project would not be possible.

Finally, but not the least, I thank my wife Lilly, who, with patience, understanding, support, and enthusiasm for my ministry, has courageously withstood the sacrifices of time and energy that have been placed upon her. Recognition is also due to my three sons, Stavely, Doyle, and Japheth, who continually teach me the true value of love. 
CHAPTER 1

\section{INTRODUCTION}

My interest in the work on the Bay Islands of Honduras began when, as a pastor, I realized the great need for professional workers and the need for a strategically structured program for evangelism and church growth. As I observed the situation I realized that something had to be done if the work was to make better progress. Some of the problems included poor evangelistic methods, few welltrained pastors and workers, the churches' lack of support from the local mission and pastors, and no material provisions for the departments of the church.

I have come to realize that good evangelism is measured by both the strength of qualitative members and by the number of people baptized. In recent years there have been a number of baptisms in the Bay Islands but with an almost equal number of dropouts. At present there is no emphasis on retaining newly converted members. 
Another serious problem is that some English churches will probably cease to exist in the next few years.

Presently, there is no comprehensive program to retain those who join the church. Neither is there a program to build or to bring to maturity the existing churches. All emphasis is placed on getting new baptisms. Ironically, every year there are more people baptized and added to the church books but every year there are more vacant pews. Therefore, it has been my purpose to seek solutions to these problems.

The English churches on the Bay Islands are passing through a time of extreme difficulty. If they continue to be neglected, some may close in a few years if new approaches to evangelism are not implemented. Although renewal or change is often spoken of at the level of the Union administration, it is difficult to observe any noticeable revitalization and change at the local level. It is to be hoped that this will come in the near future.

The local Union does not provide the needed personnel or resources for the maintainace of the English churches of the Bay Islands. The Bay Islands English churches are the strongest financial supporters of the organized work, yet they are the most neglected and marginalized. Most of the 
pastors of the English churches are Spanish speakers with little knowledge of English. All workers' meetings sponsored by the Union are conducted in Spanish, causing disinterest on the part of English speakers.

It seems that the Bay Islands mission leaders and pastors have been satisfied with large congregations made up of people who too often just occupy the pews. The leaders have not given much thought concerning the necessity for disciple-making. They seem satisfied with numerical growth and are blinded to the fact that the church is only healthy when it has also grown qualitatively. All energy and programs are focused on numerical growth, leaving little time or energy for nurturing members and encouraging qualitative growth.

Qualitative church growth is an indispensable requirement if the English churches on the Bay Islands are to survive. Presently there are no programs to train the English-speaking people in deeper discipleship. There are no new methods being implemented to evangelized the English speakers other than the traditional forms of public evangelism. There are no programs being established to help the members come in contact with secular minded-people. And 
there are no methods being used to improve the retention rate of newly baptized members. With these problems in mind, it has been my purpose to develop programs that will address these problems and needs.

\section{Statement of the Task}

The task of this dissertation is to analyze the growth of the Seventh-day Adventist church on the Bay Islands of Honduras, and to develop a strategy to strengthen the work among the English-speaking people.

\section{Justification for the Dissertation}

There has never been a comprehensive study of the SDA work on the Bay Islands, so most SDAs on the Islands do not have a clear understanding of the history and development of the church there.

Growth among the English-speaking congregations has been difficult and slow, with most increase coming from biological growth. Evangelism has been a challenge among the English congregations because of secularism and prosperity. Bay Islands mission leaders have placed their emphasis on evangelism among the Spanish speakers, thereby largely neglecting the English-speaking people. This neglect has 
resulted in stagnation and large numbers of dropouts and apostasies in the English-speaking churches, while growth has been realized among the Spanish churches.

\section{Description of the Project}

A brief history of the beginning of the Seventh-day Adventist church in the Bay Islands is traced using the available resources in the James White Library and the General Conference archives. A brief description of the cultural setting and the demographics of the Bay Islands is given. Then a church-growth study of the Bay Islands SDA church from 1986 to 1995 allows us to analyze the strengths and weaknesses of the English-speaking churches.

Chapter 1 deals with the current problems and challenges the English churches in the Bay Islands of Honduras are facing and points out that the best hope for the Bay Islands English churches is to encourage ministries that help the members come into contact with the unchurched. Chapter 2 discusses the cultural and historical background of the Bay Islands. It takes a brief look at the coming of Protestantism to Honduras and the Bay Islands. And finally, it gives a short description of the early history 
of Adventism.

In chapter 3 a theological concept of church-growth theory is discussed. It does this by looking at the apostolic church, precisely the church in the book of Acts. It also points out that the church was an active and vibrant organization with all the characteristics of progress and growth. Church growth has been presented as an ongoing process for the ministry of the church. Church growth must become a way of life.

In chapter 4, a church-growth study from 1986-95 indicates the growth patterns of the SDA church on the Islands, with a special emphasis on the differences in growth patterns between the English-speaking and Spanishspeaking congregations. The chapter clearly points out that presently the SDA church on the Islands has failed to implement a plan that is effective among the Englishspeaking people.

Chapter 5 presents practical methods that could be employed to strengthen the Bay Islands English churches and evangelize the English-speakers.

This project concludes with a summary, conclusions, and recommendations as to what must be done to effectively cause 
growth among the English churches.

Definition of Terms

Annual Growth Rate: Percentage of growth for a one-year period.

Demographic study: The statistical study of population in regard to size, density, and distribution.

Core group: Selected members from established churches who become the nucleus for the new church.

Mother church: Established church that sponsors the new church with personnel and needed resources.

Institutionalism: When institutions absorb too much of a denomination's personnel, money, and time, thereby hindering the church's missionary outreach.

Qualitative growth: Social/spiritual growth resulting in the enrichment of the experiences between a person and God . 
CHAPTER 2

\begin{abstract}
A CULTURAL AND HISTORICAL BACKGROUND
OF THE BAY ISLANDS
\end{abstract}

\begin{abstract}
Introduction
Since the early nineteenth century, Protestantism has become a vital force in Honduras. In its struggle for acceptance, Protestantism had to overcome the strong opposition of Roman Catholicism, which was implanted during the colonial era. Protestantism came into this area in the nineteenth century during a time of profound struggle between church and state and was later aided by the coming of democratic reform and religious freedom. These two developments were mutually reinforcing. They emphasized separation of church and state, freedom of religion, speech, and press, and other similar beliefs.

The development of Protestantism in Honduras, however, has largely been neglected by historians. There are few insights on the origins of Protestantism in Honduras, for
\end{abstract}


the number of missionaries to Honduras was limited and few nineteenth-century documents are left to tell the story of the coming of Protestantism to that part of the world. ${ }^{1}$ However, I have tried to make good use of the sources that are available.

\section{Short History of Honduras}

Central America includes the territory lying between the Isthmus of Tehuantepec in Southern Mexico and the Isthmus of Panama in the republic of Colombia. Honduras is situated in the heart of Central America, and is bounded on the north by the Caribbean Sea; the west by Guatemala, El Salvador, and the Pacific Ocean; and on the south and east by Nicaragua.

Centuries before it was discovered, Honduras, along with other Central American republics, was the seat of the highest Mayan Civilization known in the western Hemisphere. ${ }^{2}$

${ }^{1}$ There is much written on the secular history of Honduras but little material concerning the development of Protestantism in Honduras.

${ }^{2}$ Tim L. Merrill, ed., Honduras: A Country study (Washington, DC: Government Printing Office, 1995), 3-10. 
The remains of that ancient culture, traces of which are still extant in its temples, palaces, pyramids, and monuments, are most remarkable. ${ }^{1}$

Approximately two decades after Columbus discovered Honduras in 1502, permanent settlements by Europeans began, leading to continuous rivalry between the indigenous Indians and the Spanish immigrants. ${ }^{2}$ Some stability ${ }^{3}$ was achieved when the first territorial governor was appointed by spain in 1526, but eleven years later a major war broke out between the Spanish and the Indians. Lempira, commanding the Indian force of about 30,000 warriors, was able to hold off the Spanish until his death in 1539. The Indians were finally defeated, with the result that their population continued to decline because of enslavement and disease brought into their territory by the Spanish.

\footnotetext{
${ }^{1}$ Remains of Mayan temples are still in existence today in Copan, Honduras.

${ }^{2}$ Robert S. Chamberlin, The Conquest and Colonization of Honduras, 1502-1550, 2d ed. (Washington, DC: Carnegie Institution, 1966), 8-24.

${ }^{3} \mathrm{~A}$ form of government was set up by Spain, and rivalry between the Indians and Spaniards ceased for a few years. Both the Indians and the Spaniards were to receive a rightful place in the country, but the Indians remained enslaved.
} 
After 1570 Honduras was placed under the command of the Captaincy General of Guatemala. Independence from spain came for Honduras and all Central America in 1821 in the wake of the Mexican independence movement. In 1823 the Central American States formed the United Province of Central America. Honduras eventually withdrew and declared its own independence in $1838 .^{1}$

\section{Brief History of the Bay Islands}

The Bay Islands are a magnificent chain of tropical islands approximately forty miles off the northern coast of Honduras. The rich cultural history of the Bay Islands dates back to the ancient and highly advanced Mayan civilization, but today the islands have a distinct mixture of English and Spanish cultures, customs, and traditions.

When Columbus first arrived in the Bay Islands on his fourth voyage to the New World, between 1502 and 1504, he sailed into the harbor just north of $\mathrm{El}$ Soldado beach, ${ }^{2}$ which is located on the northwest shore of the Bay Island of Bonacca. His visit is now commemorated by a small monument.

\footnotetext{
${ }^{1}$ Ibid. , 60 .

${ }^{2}$ Merrill, 5 .
} 
During the seventeenth century, British pirateering increased, and the British buccaneers ${ }^{1}$ often hid with their stolen goods in the sheltered ports of the Bay Islands. Henceforth, the English slowly took possession of the Bay Islands, and over the next two centuries they were considered British territory. A permanent settlement was established on the Island of Roatan, challenging Spanish dominion. ${ }^{2}$

On November 28, 1859, England signed a treaty ending years of conflict by ceding the Bay Islands to Honduras. ${ }^{3}$ But it was not until 1861 that the British ended their sovereignty of the Islands." Since then, the Bay Islands have been ruled by Honduras.

${ }^{1}$ Buccaneer refers to a pirate. The word is derived from the word boucaner, meaning "to cure meat." This meat was used by the pirates on their long voyages.

${ }^{2}$ Troy S. Floyd, The Anglo-Spanish struggle for Mosquitia (Albuquerque, NM: University of New Mexico Press, 1967), 18 .

${ }^{3}$ Treaty Between Her Majesty and the Republic of Honduras, Respecting the Bay Islands, the Mosquito Indians, and the Rights and Claims of British Subjects (London: Harrison and Sons, 1860), 1-5.

${ }^{4}$ Caroline Warren, Utilla, to Drusilla Borden, Roatan, 24 June 1941, photocopy, in my possession. 
In recent years many people from mainland Honduras have taken advantage of Bay Islands jobs in the fishing industry and, increasingly, in the tourist industry. This influx of new immigrants adds greater diversity to an already rich cultural landscape. The Bay Islands bilingual history and varied traditions are reflected in all aspects of the culture, from bilingual schools to the variety of churches and commercial enterprises.

\section{Protestantism and Missions in Honduras ${ }^{1}$}

The introduction of Protestantism to the Bay Islands and Honduras was most helpful and instructive. Nevertheless, because of time and space I will only briefly summarize the main events that led to the development of Protestantism there. I begin with the determination of dates and sequences of events in the introduction of the few organizations that entered Honduras. To do this, we begin where it first started, the Bay Islands of Honduras.

${ }^{1}$ When speaking about Honduras, I mean continental Honduras and not the Islands. 
Religious History of the Bay Islands

It was not until 1812 that Honduras was influenced, in

a small way, by Protestantism. ${ }^{1}$ Prior to A. E. Bishop's and

J. G. Cassel' $\mathbf{s}^{2}$ arrival to the interior of Honduras,

Protestantism had already entered Honduras through the

activities of the British in the Bay Islands, the Wesleyan

Methodists from Belize, and the American Bible Society. ${ }^{3}$ The

Wesleyan minister, Harmon Mason, was the first missionary

who visited the Bay Islands of Roatan and Utilla. He

arrived in Utilla in the year 1852, and succeeded in forming

a Methodist society at the Cays in Utilla. Mason arrived

${ }^{1} \mathrm{~F}$. de P. Castells, "Central America as a Mission

Field," Missionary Review of the World 14 (March 1901): 168 176.

${ }^{2} \mathrm{~A}$. E. Bishop had been a member of the Methodist church, but he withdrew from the church because of theological differences in eschatology and soteriology. He, along with others, organized the Gospel Missionary Union in 1896, which encouraged Bible study, fundamental doctrine, and propagating the gospel in unevangelized areas. Then in the latter part of the nineteenth century, he and J. G. Cassel accepted the challenge to establish Protestantism in the interior of Honduras. They established what was called the Central American Mission. Three words, Evangelical, nondenominational, and evangelistic, characterized the policy and purpose of the Mission.

3"Field of Monthly Survey: Central America," Missionary Review of the World 17 (March 1894): 218 . 
from Belize, preached to the people, pointed them to Christ, and a change for good took place at once. ${ }^{1}$

Soon after the establishment of the church, Warren was one of the first converts and the first of the brethren who conducted worship. Others of great influence, such as ward Morgan and Henry Cooper, were soon converted and helped in worship services afterwards. ${ }^{2}$

James Cooper, with the support of John Howell, conducted weekly prayer meetings in Thomas Howell's home. In a short time two prayer meetings were held weekly, Morgan leading in one. "These were increased until one was held every night of the week and one early on sunday mornings." 3 This was the beginning of the Wesleyan Methodist Church on the Bay Islands of Honduras. Protestantism in the Bay Islands was able to take root at this early date because the Islands were in British possession. When Britain ceded the Islands to Honduras in 1856, the treaty provided for continuing religious freedom.

${ }^{1}$ Richard H. Rose, Utilla: Past and Present (Dansville, NY: F. A. Owen Publishing Company, 1904), 72-92.

${ }^{2}$ Ibid.

${ }^{3}$ Ibid. 
The Entrance of Protestantism in

Honduras and the Bay Islands

Several factors made the establishment of Protestantism possible in Honduras. First, most of its inhabitants lived in poverty as Honduras was an underdeveloped country. Protestantism brought hope and a change of lifestyle. It provided the people with an opportunity to look for something better. Second, Catholicism was not as strong as it appeared, for the clergy were understaffed, many places were without a resident priest, and most of the people were only nominally related to the church. ${ }^{1}$ Moreover, although Catholicism had usually enjoyed constitutional privileges since independence from Spain, it was deprived of those favors through the separation of church and state in 1880 . Third, there is evidence that large numbers of Bibles were smuggled into these provinces in various ways. ${ }^{2}$ This was the beginning that led Honduras to the religious freedom it enjoys today.

${ }^{1}$ Wilkins B. Winn, Pioneer Protestant Missionaries in Honduras (Cuernavaca, Mexico: Cidox Dossier, 1973), 2-3.

${ }^{2}$ Castells, $170-174$. 
The British and Foreign Bible society entered the Bay Islands in 1812. They distributed Bibles to the early settlers of the Bay Islands of Honduras, assuming without question that the settlers were Protestants. ${ }^{1}$ At the time, it was still a criminal offense to introduce the word of God into the Spanish territory of continental Honduras. Religious freedom did not come until 1880, ${ }^{2}$ when the administration of Marco Aurelio Soto introduced a bill providing for the separation of church and state that succeeded in establishing complete religious freedom. ${ }^{3}$

The next Protestant group to enter the Bay Islands was the Jamaica Baptist Missionary Society, which started work in Belize, Roatan, and Bonacca. The Baptist work was begun in 1822, when the Baptist Missionary Society sent a missionary to Belize. This led to the formation of a church, which, though left to support itself in 1847 , continued to

${ }^{1}$ Ibid. , 170 .

${ }^{2}$ Floyd $J$. Mecham, Church and state in Latin America (Chapel Hill, NC: The University of North Carolina Press, 1966), 327 .

${ }^{3}$ E. Dussel, R. Cardenal, R. Bendana, J. E. Arellano, M. Carias, M. Picado, and W. Nelson, Historia General de la Iglesia en America Latina (Cehila, Espana: Salamanca, 1985), $226-240$. 
do so and acted as a missionary force in the regions surrounding the colony. ${ }^{1}$

Following these developments, A. E. Bishop and J. G. Cassel accepted the call and challenge in the latter part of the nineteenth century to establish Protestantism in the interior of continental Honduras. ${ }^{2}$ This call demanded courage and strength of mind to pioneer such a ministry in an area that had long been under the influence of Roman Catholicism. Not satisfied to remain along the coastline, they went inland to spread the word of God and share their faith. In 1896, Santa Rosa de Copan became the center from which Bishop fought to evangelize the native people in the surrounding towns. ${ }^{3}$ Later on, Cassel moved to the east of Honduras in the department of Gracias, the center from which Cassel sought to permeate the country with his faith. ${ }^{4}$ These men laid the foundation for a Protestant movement in continental Honduras which today is still very strong.

\footnotetext{
${ }^{1}$ Castells, 171-172.

${ }^{2}$ Winn, 3-11.

${ }^{3}$ Ibid. , 5 .

${ }^{4}$ Ibid.
} 


\section{Adventist History}

Elizabeth Elwin was born February 3, 1840, as the eldest of twelve children. Her father was Governor of the Bay Islands when they were owned by England, and it was in the Bay Islands that she spent most of her early years. Her father sent her to school in Belize where she obtained sufficient education to teach her brothers and sisters. ${ }^{1}$ Elizabeth married Mr. Gauterau and went to New York in 1867, and later to San Francisco. It was while in san Francisco that Mrs. Gauterau attended a Seventh-day Adventist camp meeting in Oakland, California, and accepted the Three Angels' Messages.

Upon accepting the Adventist message, Mrs. Gauterau began to send tracts, magazines, and other Christian materials home to her family in the Bay Islands and Belize. She was filled with a burning desire to bring the message personally to her family and friends in the Bay Islands of Honduras.

On December 9, 1885, Mrs. Gauterau left for her long voyage to the Bay Islands. Arriving in Belize on the 22 nd of

${ }^{1}$ Gilbert D. Curtis to Mary P. Elwin, $15 \mathrm{July} 1979$, photocopy in my possession. 
December, 1885, she shared with her friends and neighbors her newfound faith. She states:

I did missionary work at Belize, could sell all the papers and tracts I had. People all over are greatly interested in this Third Angels [sic] Message. Wrote for more books, papers and tracts. . . I feel so good in doing the work for the Lord. . . It has made me so happy. ${ }^{1}$

She arrived at her mother's home on the island of Roatan on

a Friday evening in early February of 1886, nearly two months after she had left her home in San Francisco. Of this experience she wrote:

All arose early Sabbath morning in our home and gave thanks to our Heavenly Father, found other Sabbath Keepers. . . . Oh, how my heart was full of love and thanks to the almighty God for all his blessing and light from above shone upon my dear mother, brothers, and sisters who were earnestly trying to do His precious will. . . . Our joy was too great for pencil to describe. We had a glorious Sabbath-day with the Lord and each other, at our home in Brick Bay. A beautiful sabbath morning, oh, a perfect heaven on earth, all peace and joy, nothing to mar our joy as we studied God's word. ${ }^{2}$

She gave thanks to God for others who found the joy of keeping the Sabbath. "And after more than six months laboring in the Bay Islands she left thirty-five people

\footnotetext{
${ }^{1}$ Ibid.
}

${ }^{2}$ Ibid. 
keeping the Sabbath."1 At this time there was no church organized, but as a result of her effort, in 1892 , the Bonacca SDA church was organized. Thus began the work of the Seventh-day Adventists in the Bay Islands of Honduras and Central America.

The manner in which Mrs. Gauterau went about her missionary work revealed her strong character and dominant personality. She displayed such qualities as courage, determination, and persistence. She possessed a strong sense of calling that was daily reinforced by private devotions. ${ }^{2}$ She certainly manifested a tenacity of purpose in working under extenuating circumstances. She constantly experienced the problem of extensive travel by sailboat or dory, which was necessary to consummate the evangelization of the Islands. Without the aid of existing institutions ${ }^{3}$ on the Islands, she tackled the problems of a pioneer ministry to establish a group of supporters through personal evangelism. Mrs. Gauterau used her ingenuity in developing

${ }^{1}$ Ibid.

${ }^{2}$ Ibid.

${ }^{3} \mathrm{At}$ this time there were no churches, schools, or other organized missionary groups. 
various procedures and methods in her ministry. Alert to every opportunity such as teaching, prayer meetings, tract distribution, and house-to-house visitations, she is to be admired for the sacrifice she made in behalf of her faith. In December of 1891, the General Conference sent its first official worker, Frank J. Hutchins, to the Bay Islands, who set up headquarters in Ruatan. ${ }^{1}$ on arriving in Ruatan, Hutchins found that several of the local people believed in the Sabbath. After a short time, a company of thirty-three believers was organized. ${ }^{2}$ On the island of Bonacca, where there was no worker except for the missionary endeavor of the local people, the work was so well advanced that within seven weeks of Hutchins's arrival on that island in 1892, the first SDA church was organized. In 1893 the church building was dedicated. In his discourse before the delegates and committee members of the General Conference on February 7, 1895, Hutchins stated:

1 "West Indies and Central America," General Conference Daily Bulletin 5, no. 11 (February 17, 1893): 281.

2"Fifteenth Meeting, Thursday, 9:30 A.M., February 23," General Conference Bulletin 8, no. 9 (February 26, 1899): 83. 
At the end of this time, we did not know what to do, but the way opened as a steamer arrived, and the American consul, in whose house we were living, invited us to go to Bonacca the next day on her. We concluded to go. We were treated cordially and found a good class of people. They found out that I was a minister and wanted me to preach that evening. I consented, and we had a very good meeting. The little house was well filled. Friday evening we expected to return to Ruatan, so we took as our subject for that meeting, Romans 2:6, and brought in the ten commandments as the will of God, and showed that the Sabbath as given in the fourth commandment was also a part of his will. After the meeting was over, we asked them how many could see and fully believed that the ten commandments really were the will of God and the Sabbath really meant the seventh day, as the commandment said. There were twenty-one that arose to their feet. It was six weeks before we returned: but some of those who had heard the truth had taken their stand for it, and on our return fifteen signed the covenant, and we organized a church of thirteen. And every quarterly meeting since that time there has been a baptism of from one to three, and now there is a church of thirty members. ${ }^{1}$

By the year 1895, there were almost one hundred members belonging to three organized groups of believers. Two organized companies were on the island of Bonacca. A. J. Haysmer states, however, "We have only one organized church there. It is divided into two companies, but is only one

1 "Central America," General Conference Daily Bulletin 1, no. 3, extra vol. (February 11, 1895): 95-97. 
church."1 One was on the Cay ${ }^{2}$ of Bonacca, which had its own building, and the second organized company was at an unspecified location on the main island on Bonacca. By the end of 1895, this company also had its own church building. ${ }^{3}$ The third organized company was in French Harbor on the island of Ruatan. The French Harbor company was organized with thirty-three members by Hutchins days after he arrived in Roatan in the year 1891." "They continued to worship in the home of Christopher Jones for a long time and on May 27th, 1905, the first SDA church was free of debt and was 1"Fifteenth Meeting, Thursday, 9:30 A.M., February 23," 83.

${ }^{2}$ Cay is a small island.

"Central America," 95-97.

${ }^{4}$ Until more material surfaces, I have given a reasonable account of the material that has been available in the General Conference files. Therefore, as I see it, an organized church meant an organized group of believers who had their own church building. An organized group of believers who did not have a church building was referred to as an organized company. The General Conference Bulletin 5, no. 12 (February 20, 1893): 290, states that the church in Roatan was organized in 1891. But nowhere else do we find any reference or comments on the organization of this church. 
dedicated by H. C. Goodrich, president of the International Tract Society."1

The believers in the Bay Islands were firm in their faith in the Three Angels' Messages. From time to time ministers from the United States would visit the Bay Islands to encourage the advancement of the Three Angels' Messages there. By 1908 the first campmeeting was held on the Island of Roatan by Elder spicer, which resulted in the building of a new church. ${ }^{2}$

The ministers gave much strength to the believers and held tent meetings, causing the church to grow and prosper. ${ }^{3}$ The other ministers continued the pattern of ministry that Hutchins had previously established. Personal witnessing, house-to-house visitation, and distribution of tracts remained a basic part of the work. ${ }^{4}$ The crowds at the tent meetings and other general gatherings provided further

${ }^{1}$ Mary P. Elwin, handwritten Ms, July 15, 1979, French Harbour SDA church, transcription in my possession.

2 "Report of the Central American Conference," General Conference Daily Bulletin 6, no. 20 (June 6, 1909): 338 .

${ }^{3}$ Ibid.

4 "International Tract Society," General Conference Bulletin 1, no. 7, extra vol. (February 18, 1895): 211. 
opportunities for the distribution of tracts as well as the singing of hymns, preaching, and baptisms. In addition, as converts visited the other islands during these occasions, they enjoyed the religious celebrations and fellowship with the missionaries.

The members were so enthusiastic about the work started by Hutchins that they started to make plans for the construction of a fifty-foot missionary launch (boat). The Sabbath School offerings from around the world were used for this purpose, and in 1897 the launch "HERALD" sailed the waters to take the message from the islands to Nicaragua, Costa Rica, Panama, and even Colombia. ${ }^{1}$

The establishment and maintenance of schools constituted another aspect of the work. With the opening of the Bonacca school on July 4, 1894, W. A. Miller and his wife from California came and took charge of the school, which had an average attendance of thirty-nine in 1894, increasing to forty-five students in $1895 .^{2}$ Another school

'Don, F. Neufeld, ed. "Honduras" Seventh-day Adventist Encyclopedia, Rev. ed. (Washington, DC: Review and Herald, 1976), 597 .

2"Report of Educational Secretary," General Conference Bulletin 1, no. 8, extra vol. (February 19, 1895): 222. 
was established in Utilla in 1900 with Winifred Holmden as director and teacher. During the first four decades of Adventism, the Bay Islands experience many changes in its development and growth. Until 1905 the Bay Islands and British Honduras (Belize) "were considered a single mission field, which was referred to as the Central American Mission. ${ }^{1}$ In 1905 there were 160 members in five organized churches and companies in this field, most of which were on the Bay Islands. In 1908 Guatemala and El Salvador were included as part of this field, and it was renamed as the Central American Conference (CAC). In 1913 the CAC was administered directly under the General Conference, and was renamed the Northern Spanish American Mission. In 1918 Honduras and Belize were organized as one Mission once again, and called the Honduras Mission. In 1922 the Honduras Mission was included in the Inter-American Division. ${ }^{2}$ Since that time the English church has grown in numbers, but there has not been any significant emphasis placed on church planting among the English-speaking churches. In the early

\footnotetext{
${ }^{1}$ Neufeld.

${ }^{2}$ Ibid.
} 
1970s one English church were organized on the Island of Roatan. Between 1970 and 1995 five primary and three secondary schools were establish but not one English church was planted.

Today, the Seventh-day Adventist work in the Bay Islands has grown to include six primary schools, four secondary schools, and eighteen churches with almost four thousand members.

\section{Conclusion}

This chapter has given a brief history of both Honduras and the Bay Islands. It also has given a summary of the entrance of Protestantism to the Bay Islands and Honduras. It has been seen that the Seventh-day Adventist message entered Central America in a small way as early as the late 1870s when Elizabeth Gauterau began to send tracts and Christian literature home to her family in the Bay Islands. But it entered in a more personal way when Gauterau went back home and labored for the Lord until her death.

The SDA church became fully organized, however, when Frank J. Hutchins arrived as the first official missionary from the General Conference in 1891. He found many already 
grounded in the Adventist truths and so was able to organize them into churches and companies.

Recognizing, therefore, that the local Seventh-day Adventist church is a resource center for a church-planting offensive, and that evangelization is a process which grows out of the nature of the church as a redeemed community of people who have been made stewards of the grace of God, the theory and practice of church growth is discussed in chapter 3. 


\section{CHAPTER 3}

\section{CHURCH-GROWTH THEOLOGY AND PRACTICE}

\section{Introduction}

The relationships that men and women develop with others are usually a reflection of their relationship with God and are related to church growth. ${ }^{1}$ The Bible gives ample evidence of God's caring relationship with His creation and especially with humanity, the crowning act of His creation.

A correct awareness of God's love and care is necessary for a true representation of God's character. People who live for themselves often believe that relationships are self determined and that outside influences have no more interaction on one's life than passing scenery. ${ }^{2}$ With great frequency, however, relationships develop as "a product of

${ }^{1} \mathrm{John}$ Powell, Unconditional Love (Niles, IL: Arguq Communications, 1978), 110-118.

${ }^{2}$ William A. Smalley, ed., Readings in Missionary Anthropology II (South Pasadena, CA: William Carey Library, 1978), 701 . 
those who have loved us or refused to love us."1

This lesson of love is what Jesus taught when He talked about bearing the cross and risking life itself for His sake (Mark 8:34-38). Jesus later referred to His own death when He spoke of a grain of wheat that becomes part of the harvest only after it dies in the ground (John $12: 24-26$ ). Part of the mystery of church growth is that God can make something new and meaningful out of a church that allows its past to become a bridge for its future.

The church must minister with love and humility, with a deep sense of its calling, and with the authority of the Lord Jesus Christ Himself, who said:

All power is given unto me in heaven and in earth. Go ye therefore, and teach all nations, baptizing them in the name of the Father, and of the Son, and of the Holy Ghost (Matt 28:19).

Such is our calling.

If the church is to be the kind of institution that the Lord Jesus Christ intended it to be, then it must minister to the whole person in its existential setting, under the socioeconomic, political, and circumstantial situation where

\footnotetext{
${ }^{1}$ Robert Powell, Why Am I Afraid to Love? (Allen, TX: Argus Communications, 1967), 29.
} 
it might find itself.

\section{Ministry of the Church}

Before the issue of church growth is addressed, however, we must have in mind the basic elements of church ministry. Jesus expressed to the Father in John 17:18, "As you sent me into the world I have sent them into the world." He established and anointed the church to continue His work in the world.

I think this is our bold privilege. It is no aspect of the prize of the high calling of God in Christ Jesus. As Thou hast sent me into the world even so have I also sent them--to preach, to heal, to deliver, to open the iron gates, to be ambassadors of a glorious freedom for body, mind and soul.1

Therefore, the ministry of the church is the ministry of Christ.

Eusebius recorded that the post-apostolic believers inspired by the holy word sacrificially evangelized and instilled into their converts the books of the divine Gospels. ${ }^{2}$

1J. H. Jowett, The Preacher: His Life and Work (Grand Rapids, MI: Baker Book House, 1976), 32 .

${ }^{2} J o h n$ Calvin, Institutes of the Christian Religion, 2 vols. (London: James Clark Publishing Co., 1959), 2:318. 
The disciples' mission did not center on "what do we proclaim? nor how do we proclaim? but whom do we proclaim?"1 Luke confirms that the gospel found its focal point in Christ. He states that the apostles talked of Jesus as the "raising Lord" (Acts 3:26), the "approved of God" (Acts 2:22), "glorified by God" (Acts 3:13), and "standing at the right hand of God" (Acts 7:55). The disciples spoke with certainty of the Lordship and the resurrection of Jesus (Acts $11: 20 ; 17: 18$ ). So certain were they of their gospel that they knew there was no salvation in anyone else but Christ (Acts 4:12). The apostles themselves became the content of the gospel they proclaimed. ${ }^{2}$

God has acted in the historical past, He acts in the present, and He will continue to act in the future.

\section{Growth as the work of God}

The revelation and work of God in the world are found throughout all of scripture. It is not wise to devise a plan

${ }^{1}$ James B. Torrence, "The Place of Jesus Christ in Worship," in Theological Foundations for Ministry, ed. Ray S. Anderson (Grand Rapids: Eerdmans, 1979), 358.

${ }^{2}$ Michael Green, Evangelism in the Early Church (Grand Rapids: Eerdmans, 1970), 51. 
of action apart from the ministry of Christ Himself, for we are reminded that all ministry comes from Christ. Theology takes place in the presence of Jesus who is revealed in His continuing ministry of reconciliation through the Holy Spirit. Thus, Jesus is not only the subject of the gospel, He is the proclaimer in every act of revelation. Theological reflection does not ask the question, "What would Jesus do in this situation?" but rather, "Where is Jesus in this situation and what am I to do as His minister?"1

The foundation for all ministry is the proclamation of Jesus. Clearly, the cornerstones with which Christ builds His church are proclamations of the gospel. ${ }^{2}$ The spoken word, proclaimed by the human instrument under the power of the Holy Spirit, impels the hearer to respond to its truth, for all throughout history the Bible was an oral word to the people. The New Testament confirms and encourages this continuation of the oral tradition by stating that faith is built by the hearing of the word of God (Rom 10:14-17).

${ }^{1}$ Ray S. Anderson, Theological Foundations for Ministry (Grand Rapids, MI: Eerdmans, 1979), 7.

${ }^{2}$ Waldo J. Werning, "Biblical Church Growth," Globas (January-March 1994): 3 . 
Preaching, then, is central to the task of the church. People must be exposed to the gospel truths revealed by Jesus Himself. The presentation of the gospel in clear, precise form in public exhibition exposes hearers to the central truth and theme of the gospel. This requires preaching not only the concepts of truth but also offering life applications for the hearers.

People are moved, persuaded and their lives formed essentially through preaching, namely, through preaching which regards itself and offers itself as that which confirms the fulfillment of the promise which therefore establishes the bases for that courage to be and the strength to work. ${ }^{1}$

Proclamation is intended to reveal God's word in such a way that people can understand its meaning. God has given this authority of the word to pastors as overseers of His church so people might worship and serve in unity. ${ }^{2}$

Preaching must be first and foremost grounded in the ministry of Jesus Christ. Contemporary society is, by and large, ignorant of the theological themes in scripture. If these themes are introduced in a cold, dull, boring,

${ }^{1}$ Kornelis Miskotte, Theological Foundation for Ministry (Grand Rapids, MI: Eerdmans 1979), 680.

${ }^{2}$ Ibid. , 441 . 
theoretical manner unapplied to contemporary society, the answer to the common question will be "So what?" Therefore, the preacher must, in the telling of salvation's history, "re-enact the word event of God's promise to the world, for the sake of reconciliation." We live in a world ignorant of the fundamentals of theological and biblical knowledge. Modern man has been literally ruined emotionally, spiritually, and physically. Preaching must not only bring reconciliation between God and man but also between man and his fellow human beings as well as between man and himself in today's society.

\section{The Ministry of Incarnation}

All true evangelism is incarnational, personal, and individual. In the complexity of our world we have indulged self and neglected to care for the souls and bodies of those for whom Christ has given His life. "Because we cannot deal with the many as individuals, we sometimes try to simplify the many into an abstraction called the mass. But can one

${ }^{1}$ Anderson, 496. 
really feel deeply for the mass?"1 This problem has so directly affected the church that in recent years we have tended toward a hand-grenade approach to evangelism.

When the New Testament had its great ingathering (Acts

2) there was no resource other than that of the Holy spirit. The spirit so empowered the ministry of the early church that its growth was unprecedented. Methods are good and we cannot function without them; however, any method apart from the resource of the Holy spirit will be of no consequence. Jesus stated that we are to go and minister to the world (Matt 5:13-17; 13:38; Mark 3:14; Phil 2:15). The example illustrated in Scripture is one of practical involvement with the world. We must be involved in relieving the pain and discomfort of humanity. The pure gospel is not concerned merely with the promulgation of man's spiritual destiny. Unity of interests with Christ means solidarity with the world in its present condition.

Ministry is done by people, and the individual is of supreme importance. In our world, institutions have, in many instances, taken the place of the person; but building an

${ }^{1}$ Anne Morrow Lindbergh, Gift from the Sea (New York: Random House, 1975), 125. 
institution is not the goal of the ministry of Christ. The real goal is to build people.

From this fundamental base new ministries are developed so that other people and other groups might be reached. We do not start new ministries because it is nice, or to have a particular program, nor do we start new ministries because certain evangelists have been successful. ${ }^{1}$ We start a new ministry on the basis of where God is working and where we see His hand at work in the lives of individuals who have been brought into the integrated fellowship of the body of Christ.

In the widening horizon of today's world, people need, more than ever, a place where they belong. ${ }^{2}$ The church will never be able to adequately address this need if we confine our ministry to public meetings where people are seated in rows, silently facing a speaker. Yes, proclamation is central to the church's ministry, but so also is community. The best way, therefore, to produce community is through the

${ }^{1}$ George Patterson and Richard Schoggins, Church Multiplication Guide (Pasadena, CA: William Carey Library, 1993), 3-8.

${ }^{2}$ Paul Tournier, A Place for You (New York: Harper \& Row Publishers, 1968), 12-13. 
planting of churches and following God's command by penetrating the social circles. ${ }^{1}$ In other words, we should carry the church to the people's homes not expecting the people to integrate into a church that does not relate to their customs and practices. ${ }^{2}$

\section{Holistic Ministry of the Church}

It is as we conceive the church as a body, and as part of that body, that we will be able to understand the principle that, "Being many, we are yet one body." ${ }^{3}$ It is a paradox that must be clearly understood in order for Christians to function as individuals within a community. If we can come to grips with the idea that we do not cease to be individuals when we become fused into a body, but that we become one in Christ, then we will be able to show the world that the church is an organism made up of people who are sufficiently free to be able to live in a

\footnotetext{
${ }^{1}$ Patterson and Schoggins, 3.

${ }^{2}$ Ibid.

${ }^{3}$ Jowett, $32-36$.
} 
community. ${ }^{1}$ How well Elizabeth O'Connor puts it: "They had found what it was to be real persons in community." ${ }^{2}$

"The Church, so understood," says a distinguished writer, "brings together many persons, is a community, and has unity, although it is not without conflict of wills."3 What makes the church a new type of community is that "the Holy Spirit lives in it."4 How are we to grow? The apostle Paul telis us how: "For as the body is one and has many members, but all the members of that one body, being many, are one body, so also in Christ" (1 Cor 12:12). Each member must contribute to the growth of every other member. The church is not a group of isolated members joined to a head but separated from one another. The Holy spirit operates in and through each member to make increase of the body. The church, therefore, should be a community to integrate each

${ }^{1}$ Duncan McIntosh and Richard E. Rusbuldt, Planning Growth in Your Church (Valley Forge, PA: Judson Press, 1983), 17-19.

${ }^{2}$ Elizabeth O'Connor, Call to Commitment (New York: Harper and Row, Publishers, 1975), 160.

${ }^{3}$ Dallas M. Roark, Makers of the Modern Theological Mind: Dietrich Bonhoeffer, ed. Bob E. Patterson (Waco, TX: Word Books, 1976), 33 .

${ }^{4}$ Ibid. , 34 . 
member in a plan that will make members who will be responsible in the proclamation of the gospel, for it is those who are most actively working in winning souls for Christ that are best developed spiritually. The church should be an incubator where the weak can become strong, where members will not only be taught the science of salvation, but become skillful in the proclamation of the gospel.

The Apostolic Ministry

During the expansion and growth of the early church, the apostles' preaching and teaching was not mere formality; their presentations were delivered with urgency and they expected a response. King Agrippa sensed the power and spirit of Paul when he said: "In a short time you think to make me a Christian!" (Acts 26:28). So fervent were their messages that the hearers sometimes responded with, "What shall we do?" (Acts 16:30).

The reason for this evangelistic thrust of the apostolic church was their comprehension of the work and person of their Christ. They had seen Him work, teach, and preach, and they themselves had been taught by Him. Now they 
had a new vision of the kingdom of God and His purpose for humanity. They were now compelled to witness to the "unsaved." With the belief that there is salvation in no other name but Christ's (Act 4:12) the apostles found an incentive for church growth. Their zeal for the gospel was "rooted in what God is and what he has done for man through the coming and death and the resurrection of Jesus." 1 Their entire work was conducted on so high a plane as to be above the shadow of suspicion. Their minds were directed to scriptures and to the person of Christ, rather than to individuals. Their own testimony confirms this, "We cannot but speak of what we have seen and heard" (Acts 4:20). Thus the foundation for church growth was established.

\section{The Church: A Missionary Body}

Not only did the apostles proclaim the gospel, but the members of the newly founded church of Christ also joined in. The zeal and dedication of stephen led him to be a missionary for Christ in such a way that he risked his life for the church (Acts 6 and 7 ). The persecution that followed the death of stephen scattered the believers throughout "the 
region of Judea, Samaria, Phoenicia, Cyprus and Antioch" (Acts $8: 1 ; 11: 19)$. These believers promulgated the gospel in such a way that "a great number of believers turned to the Lord" (Acts 11:21).

The power of the gospel was not delivered only through formal preaching but through the lives and testimony of the believers themselves. After Peter healed Aeneas who had been paralyzed for eight years he, in turn, shared with the residents of Lydda and Sharon his newfound faith and led them to turn "to the Lord" (Acts 9:35). Thus the early church, along with the divine providence of the Holy Spirit and the leadership of the apostles, created an appropriate environment for church growth.

The providence of the Holy spirit enabled the disciples to be Christ's witnesses to all nations (Luke 1:1-4; Acts 1:1-11). This was the starting point for the work of the early church. Verkuyl states that Luke "views the events in Jesus' life recorded in the first book as the base and starting point for the work of the early church described in the second."1 Without the providence of God through the work

${ }^{1} \mathrm{~J}$. Verkuyl, Contemporary Missiology, trans. Dale Cooper (Grand Rapids: Eerdmans, 1978), 110. 
of the Holy Spirit, there would have been no apostolic mission. Without the life of Christ as recorded in the Gospels, there would have been no message to promulgate. Therefore, church growth is a direct result of the work of God through the Holy Spirit.

Church growth is the result of a divine plan, and not man's. It was the angel of the Lord who told Philip to meet the Ethiopian eunuch (Acts 8:26, 27), it was an angel who instructed Cornelius in a vision to meet with Peter (Acts 10:3-6), and it was Jesus who met Saul on the road to Damascus (Acts 9:6). God is perpetually involved in the growth of His church. Nevertheless, God uses His chosen instruments and qualifies them to do the work. Growth, then, is the result of Christ's never-ending ministry of reconciliation. ${ }^{1}$

\section{Growth Patterns}

Numerical Growth

Evidence of Christ's intervention in the ministry of the church can be seen in the numerical growth of the early

${ }^{1}$ George W. Peters, A Theology of Church Growth (Grand Rapids: Zondervan, 1981), 133, 134. 
church. The Jerusalem church began with about 120 members (Acts 1:15). After the day of Pentecost three thousand were baptized. The "Lord added to their number day by day" (Acts $2: 47$ ) until the number reached a record of five thousand men (Acts 4:4). After proclaiming the word in Samaria, "multitudes with one accord gave heed" to the teaching of Philip, which resulted in both men and women being baptized (Acts 8:6-11). The church throughout Judea, Galilee, and Samaria enjoyed growth as "it was strengthened; and encouraged by the Holy spirit, it grew in numbers" (Acts $9: 31)$

On Paul's first missionary journey the Roman proconsul "believed" when he saw Elymas, the magician, struck with blindness for trying to turn him away "from the faith" (Acts $13: 48,49)$. When Paul visited Macedonia, he met a woman named Lydia in the city of Philippi; she and her household were baptized (Acts 16:15). In Thessalonica, "a great many of the devout Greeks and not a few of the leading women" (Acts 17:4) accepted the good news of the gospel. In Corinth, Paul had great success when many Jews and Greeks were converted, including Crispus, the ruler of the synagogue along "with all his household" (Acts 18:4-8). When 
Paul arrived at Jerusalem after his third missionary journey, he gave a detailed report of what the Lord had done among the Gentiles (Acts 21:17-20).

With the power and might of the Holy spirit and the fervent zeal of the apostles and members, the church grew in great numbers in Jerusalem, Judea, Samaria, and to the ends of the earth.

\section{Qualitative Growth}

The ministry of the apostles not only involved proclaiming salvation to the "unsaved" with an intent to convert, but they were concerned first for the personal spiritual growth of all believers. They were concerned that the believers remain firm in their relationship with Christ (Acts 11:23), as well as "strengthening the souls of the disciples, exhorting them to continue in the faith" (Acts 14:22). So the believers were strengthened in the faith and increased in numbers daily.

The concern of the apostles for the well-being of the brethren is also seen in Acts $6: 3$ when a suggestion was made that seven men of "good repute, full of the spirit and wisdom" (Acts 6:3) be appointed to the duty of caring for 
the widows. Paul was also concerned for the personal growth of his new disciples, and it was an object of his ministry to care for them. He reminded the elders of the Ephesian Church "that for three years" he "did not cease night or day to admonish every one with tears" (Acts 20:31).

The disciples were very concerned for personal integrity. The punishment of Ananias and Sapphira served as a reminder that discipleship is a serious undertaking and should always be viewed from a godly perspective. This comes to light when dealing with the unbelieving Jews who "stirred up the Gentiles and poisoned their minds against the brethren" (Acts 14:2). The disciples were greatly protective of their new believers and gave them every opportunity to grow in the faith.

The apostles gave evidence that their responsibility was for building up a progressive church. They all had an earnest commitment to Christ. They all "devoted themselves to teaching and fellowship" (Acts 2:42), were baptizing in "the name of the Lord Jesus" (Acts 19:5), and were even willing to die for their faith (Acts $7: 60$ ).

Their commitment was not only philosophical or connected with teaching but very practical. They sold their 
goods and possessions to help those less fortunate (Acts $2: 45 ; 4: 35-37)$. Their homes were also used for social worship and fellowship (Acts $2: 46,47$ ).

They were committed to the work of evangelism. We find the disciples, as well as the members of the churches, willing to die for the testimony of the gospel (Acts $6: 12$; $7: 60$ ). The good news of salvation was taken to Phoenicia, Cyprus, and Antioch by members of the church who were scattered as a result of Stephen's stoning (Acts $8: 6$ ). The new life in Christ gave the believers a power and zeal that was inseparable, as stated so well by Green:

Baptism, in short, set the seal on conversion in every way, individual, corporate, ethical, educational, and theological. Conversion, baptism and the new life at least as far as adults were concerned, were inseparable. ${ }^{1}$

As the church grew, these qualities of discipleship became evident in the new believers.

\section{Church Organization}

The organization of the church was a result of its evangelistic focus, the expansion of Christianity throughout

${ }^{1}$ Green, 156 . 
the whole world. ${ }^{1}$ Modern church organization must preserve this universal characteristic of the church, yet it must be responsive to Christ who calls and sustains it.

The unity of the church structure can be seen in the use of the word "church" in Acts where the singular form is used for the 1ocal church (Acts 11:26; 132:1), whereas the plural is used for all the churches $(15: 41 ; 16: 5)$. The singular can be used to mean many believers in a particular locality (Acts 5:11; 8:1), but it can also mean the church at large. ${ }^{2}$ Again Ladd states:

These uses of ekklesia suggest that the church is not merely the total number of all local churches or the totality of all believers; rather, the local congregation is the church in local expression. This is a reflection of the fact that all churches felt they belonged to one another - because they jointly belonged to Christ. ${ }^{3}$

Thus the book of Acts gives definite clues as to church organization. The appointment of the seven elders indicates

${ }^{1}$ Roland Allen, Missionary Methods: St. Paul's and Ours (Grand Rapids: Eerdmans, 1962), 93.

${ }^{2}$ George Eldon Ladd, A Theology of the New Testament (Grand Rapids: Eerdmans, 1974), 353.

${ }^{3}$ Ibid. 
that organization did take place. ${ }^{1}$ Nevertheless, this was not the goal of the early church; its primary mission was to evangelize the community around it. ${ }^{2}$ Organization was formed as a link in the chain to preserve the unity and good functioning of the church.

\section{Church Planting}

The New Testament teaches that the primary task of the apostles and the early church was the expansion and extension of the church geographically. ${ }^{3}$ This task is recorded in the Acts of the Apostles and centers around the visible manifestation of the church and its growth both in its membership and in the number of churches upon the earth.

According to Luke, the work of the apostles was to begin in Jerusalem, then go to Judea and Samaria, and then to the ends of the earth $(1: 8)$. After Gentile Christianity was established, Antioch in Syria became the center for the extension of continuous church growth (13:1-3).

In the expansion of the early church we observe that

${ }^{1}$ Ibid.

${ }^{2}$ Ibid.

${ }^{3}$ Calvin, 318 
Paul used certain strategies: He viewed the expansion of mission from the perspective of provinces or regions rather than from that of cities. The Holy spirit directed Paul to Macedonia rather than to Philippi or Thessalonica (Acts $16: 9,10 ; 18: 5 ; 19: 22)$. Paul used the "best advantage possible in the service of Christ. His vision was at once personal, urban, provincial and global."1

Paul's next strategy was to establish Christian centers in the most prominent places where the knowledge of the gospel would spread. Allen states:

Paul's theory of evangelizing a province was not preaching in every place in it himself, but to establish centres of Christian life in two or three important places from which the knowledge might spread into the country round. He intended his congregation to become at once a centre of light. ${ }^{2}$

When Paul established the church in Antioch and throughout Syria he stated that "from Jerusalem and as far round as Illyricum I have fully preached the gospel" (Rom 15:19). When Paul said that he had fully preached the gospel, he meant that he had established churches, which had

\footnotetext{
${ }^{1}$ Green, $256-265$.

${ }^{2}$ Allen, 12 .
} 
such a foundation that they could propagate the gospel.

Allen makes this very clear when he says:

It is not enough for the church to be established in a place where many are coming and going unless the people who come and go not only learn the Gospel, but learn it in such a way that they can propagate it. ${ }^{1}$

Paul also made it his plan to go to the Jews first (Acts 13:46; 17:2ff.; 18:5ff.; 19:8ff.). Paul directed his gospel first to the Jews in the synagogue and tried to convince them that Jesus was the Messiah. McGavran states that the reason for this was that "he followed up groups of people who had living relations in the people movement to Christ." ${ }^{2}$

Since Paul also planned to reach both Gentiles and Jews, he taught about the universality of the Messiah and the fact that He was available to all men (Acts 13:47, 48). Since the synagogue community was composed of Jews of both the Hebrew and Greek races, Paul was utilizing natural bridges to cross into the Gentile community. ${ }^{3}$ This could be

${ }^{1}$ Ibid. , 13

${ }^{2}$ Donald A. McGavran, The Bridges of God (New York: Friendship Press, 1955), 31.

${ }^{3}$ Ibid. 
a reason why Paul took. Timothy with him. Timothy's mother was a Jewish believer and his father a Greek; Timothy could be a bridge to both Jews and Greeks in the promulgation of the gospel (Acts 16:1-5). As a mission-minded person, Paul used every available means in the proclamation of the gospel. This is the reason for the rapid expansion of the apostolic church throughout the Roman Empire.

Church planting was a necessary part of the apostolic mission. It was a many-faceted process that demanded leadership that not only wanted to see the work firmly established but also a work that continually penetrated new frontiers. The apostles' objective was to evangelize in such a way that the new disciples would so identify with the Christian movement and that they, in turn, would work for the expansion of the church. Evangelism was a way of life for every leader and member of the church. In every aspect of the work, Christ was the center and the Holy spirit the facilitator, which resulted in a church that was multiplying by leaps and bounds.

As the church grew, it not only grew in numbers but in the quality of its disciples. Those who were added to the church were committed to Christ and understood that their 
mission was to propagate the good new of the risen Savior.

Conclusion

The church was an active and vibrant organization with all the characteristics for progress and growth. The church grew in numbers and in disciples. Those added to the church were fully committed to Christ, the church, and to the work of Christ. Church growth is made possible because of Christ and is equally dependent upon Him for its sustained growth. The members of the church never lived or existed for themselves, but always to preserve its thrust and divine mission. Peters states:

A church may have the right message and a faithful and true servant of God and yet remain stagnant and dwarfed. There is no such thing as automatic, spontaneous growth. In the natural world only weeds seem to grow spontaneously. Cultivation is necessary for proper growth and is therefore a biblical concept. Not every church grows, nor can every church be made to grow unless it is willing to meet specific divine requirements for growth. Growth takes much careful and diligent cultivation. ${ }^{1}$

Church growth took place in local situations. The church was a place where its members fellowshipped, served, suffered, and gave their lives. It was a place where they

\footnotetext{
${ }^{1}$ Peters, 133,34 .
} 
made their contributions, shared their goods, and celebrated their victories. "In all reality the local congregation becomes the manifestation of the church universal." ${ }^{1}$ All methods of growth were involved in the expansion of the early church. Church growth was not presented as an option but rather as the very heart of evangelism.

Church planting has been presented as an ongoing process for the ministry of the church. "Church growth must become a way of life for the entire church, not an appendage designed as a life-support system for a dying church. Having established the theological reason for church growth, chapter 4 consists of a church-growth study of the Bay Island̆s

\section{${ }^{1}$ Ibid.}

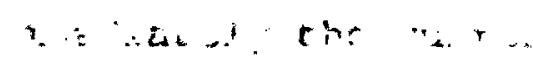


CHAPTER 4

A CHURCH-GROWTH STUDY OF THE BAY

ISLANDS , 1986-1995

\section{Introduction}

Isaiah the prophet saw a vision of the Lord in His glory, "high and lifted up." After his lips had been touched with a coal of fire from off the alter and had been thereby cleansed and fitted for his proclamation of God's word, he heard the question, "Whom shall I send, and who will go for us?" His ready answer came, "Here am I; send me" (Isa 6:1-8). And immediately the surrendered prophet received instructions as to what was involved in his mission and the difficulties that he must face.

Many workers are very conscious that the Lord has called them to be His ambassadors. So often, however, they start out with only a vague and imperfect idea as to the variety of challenges they shall face and to the way in which they should meet them. The sudden impact of life, the 
57

changing world conditions that they had not imagined, and the necessary adjustments to contemporary society sometimes demand almost more than they are prepared to give. Frustration, disillusionment, discouragement, and rejection are the result.

Conference workers and pastors on the Bay Islands are passing through a time of extreme confusion. Goals and strategies that were once unquestioned are being discarded. The whole philosophy of evangelism has been brought into question, and many are taking the viewpoint that the conference goals and philosophy of the last generation are no longer applicable: to the present situation.

\section{Demographic Study of the Bay Islands of Honduras}

The Bay Islands of Honduras, which consist of eight islands and sixty-five associated cays, are recognized as a center for tourism. With the sudden increase and diversity of cultures from around the world and the boom in tourism and growth in other sectors of the economy, it is believed that the Bay Islands have great potential for cultural, financial, and economic development. The total population of the Bay Islands, according to a 1988 census, was 
$21,550 .{ }^{1}$ In 1995 the population was approximately $40,000 .^{2}$ This means that the annual growth rate for the Bay Islands represents a 9.19 percent increase per year. The population is divided into three classes with 18 percent upper class $(7,200), 47$ percent middle class $(18,800)$, and 35 percent lower class $(14,000) .3$ The three major islands, with approximately 100 square miles, form the main industrial centers of the Bay Islands.

The rather stable economy seen in the Islands is largely due to the wide diversity of fishing and tourism industries. As of July 1996, there were over 725 established businesses in the four municipalities, which support the economy and infrastructure of the Bay Islands. ${ }^{4}$ According to the population density report of 1996 , this area has a population density of 400 per square mile with a 9.19 percent average annual growth rate. Furthermore, the

'Sharon Collins, Roatan and Honduras' Bay Islands (Houston, TX: Pisces Books, 1993), 10.

${ }^{2}$ Stavely Elwin, Governor of Bay Islands, to S. P. Elwin, 27 July 1996.

${ }^{3}$ Ibid.

${ }^{4} T h i s$ information was received from the governor's office by fax on July 30, 1996. 
reports show that only 12,030 of the population have an affiliation with a church: the Methodist church having only 1,060 baptized members, the Baptist church, 600 ; the Catholic church, 1,250; Pentecostals, 700; Church of God, 875; the Evangelicals, 300; and Seventh-day Adventists, 3,580. These figures represent only baptized members of the churches, which means that approximately 28,000 people in the Bay Islands do not attend church. The need for a strategy to reach these unchurched people becomes apparent. Based on this demographic study, the church needs to take into consideration several factors.

1. The Bay Islands are a center for tourism and financial and economic development.

2. Islanders are proud of their image.

3. The SDA church, with only 3,580 members, is showing a slow growth rate whereas the population of 40,000 people is growing much faster by comparison.

4. Racial issues are not a major concern.

5. The income level of Islanders is especially good.

6. The higher income levels and the better types of occupations tend to be with the English-speaking people. 
People of the Bay Islands

The people of the Bay Islands live on several islands that are divided by miles of open water, but the people share the same identity and feelings. They share a common heritage and national character. They may vary widely in looks and beliefs, but they tend to identify with each other because of their islander heritage, nationality, experience, joys, and customs they hold in common. They share certain traits, beliefs, freedoms, and characteristics that reflect their time in history. Nevertheless, over the years many changes have taken place. The new generation, through the means of travel and education, has been exposed to pluralism, relativism, modern science, technology, business, and especially consumerism, which are producing a generation with new values and a new worldview. All these paradigms present a major challenge to evangelism.

\section{Contextual Factors}

Island people by nature are liberal and fight for freedom. In the early history, the islanders found themselves isolated and basically left to rule themselves. A 
character of independënce and love of freedom developed in them.

The government does not pose a threat in the area of freedom of religion. One is free to practice what one chooses. The government's attitude toward Christianity remains positive and supportive. Most of the government officials on the Islands are religiously inclined.

Before the economy began to grow, many left the Islands looking for better jobs. Now that there are many work opportunities and economic stability, that trend has changed. Many islanders are returning home. Added to the economic boom, however, is the great number of foreigners coming to the Islands looking for work, causing crime to increase and the infrastructure to become weak. Therefore, the collapse of old values and worldviews, mass migrations, and a population explosion have added to the already difficult task of the understaffed and inexperienced workers of the Bay Islands Mission.

The neighborhoods or communities of the Bay Islands have remained stable, especially since the economic situation is strong and improving. Although the arrival of people from other cultures and the influx of foreigners 
bring great benefits, it is not, however, problem-free. The great amount of wealth coming into the Islands has caused problems of secularism, with many people becoming more materialistic. There is an ongoing search for pleasure among young people. Drugs and liquor as well as laxness in moral standards are fast becoming prevalent. At one time these were found only in the subcultures of the outside world, but are now practiced frequently in the Bay Islands, even among the most influential.

\section{Description of Church-Growth Patterns of the Bay Islands}

This section presents the relationship between church growth and non-church growth in the Bay Islands. It traces the church growth in the Bay Islands from 1986 to 1995, in order to equitably assess the growth trends of the churches in the Islands. The beginning year 1986 was chosen because a ten-year study was made.

The evaluation criteria for church growth are depicted in figures 1-6. But the question could be asked, "Why are graphs so important?" The answer is that by depicting the year-by-year membership statistics of the Bay Islands 
churches in a graph, one is better able to understand its growth history. McGavran reminds us that

graphs present the facts of growth dramatically, but their greatest usefulness is that they enable the student to pinpoint his investigation of trends in growth at the right moments, with accurate knowledge of their magnitude, duration, and nature. ${ }^{1}$

Nevertheless, graphs may indicate the facts but they cannot explain circumstances and reasons for the results. Figures 1-6 indicate the growth or non-growth of membership and the difference in growth between the English-speaking churches and the Spanish-speaking churches. I then analyze and explain them placing particular attention on both the periods of rapid growth and the periods of slow growth. I also indicate the percentages of baptism between the English-speaking and Spanish-speaking people. The accuracy of the figures, however, depend upon the available statistics.

That the Bay Islands have experienced continuous growth during the last ten years is undisputable (see figs. 1, 2, and 5). Looking at the graphs, we note that the growth has

${ }^{1}$ Donald A. McGavran, Understanding Church Growth, rev. and ed. C. Peter Wagner, 3d ed. (Grand Rapids, MI: William B. Eerdmans, 1970), 143. 
not been among the English-speaking churches (see figs. 3 and 4), In 1985 there were ten English-speaking churches and one Spanish-speaking church. In 1995, there were a total of eighteen churches, eight of which are spanish-speaking and ten are English-speaking.

As one can observe, for every fifteen Spanish baptisms there is only one English baptism (see fig. 6). Figure 6 shows that church planting among the English-speaking people of the Bay Islands has not been a priority for the Bay Islands mission. All people must hear the gospel regardless of how difficult the receptivity may seem. Ellen white reminds us that

place after place is to be visited; church after church is to be raised up. Those who take their stand for the truth are to be organized into churches, and then the minister is to pass on to other equally important fields. ${ }^{1}$

Beginning in 1985-86 there was a significant increase in the number of baptisms. This increase in baptisms was due largely to the requirements that the yearly numbers of baptisms must increase if the Bay Islands was to be organized into a mission.

${ }^{1}$ Ellen G. White, Evangelism (Washington, DC: Review and Herald Pub. Assoc., 1946), 353. 


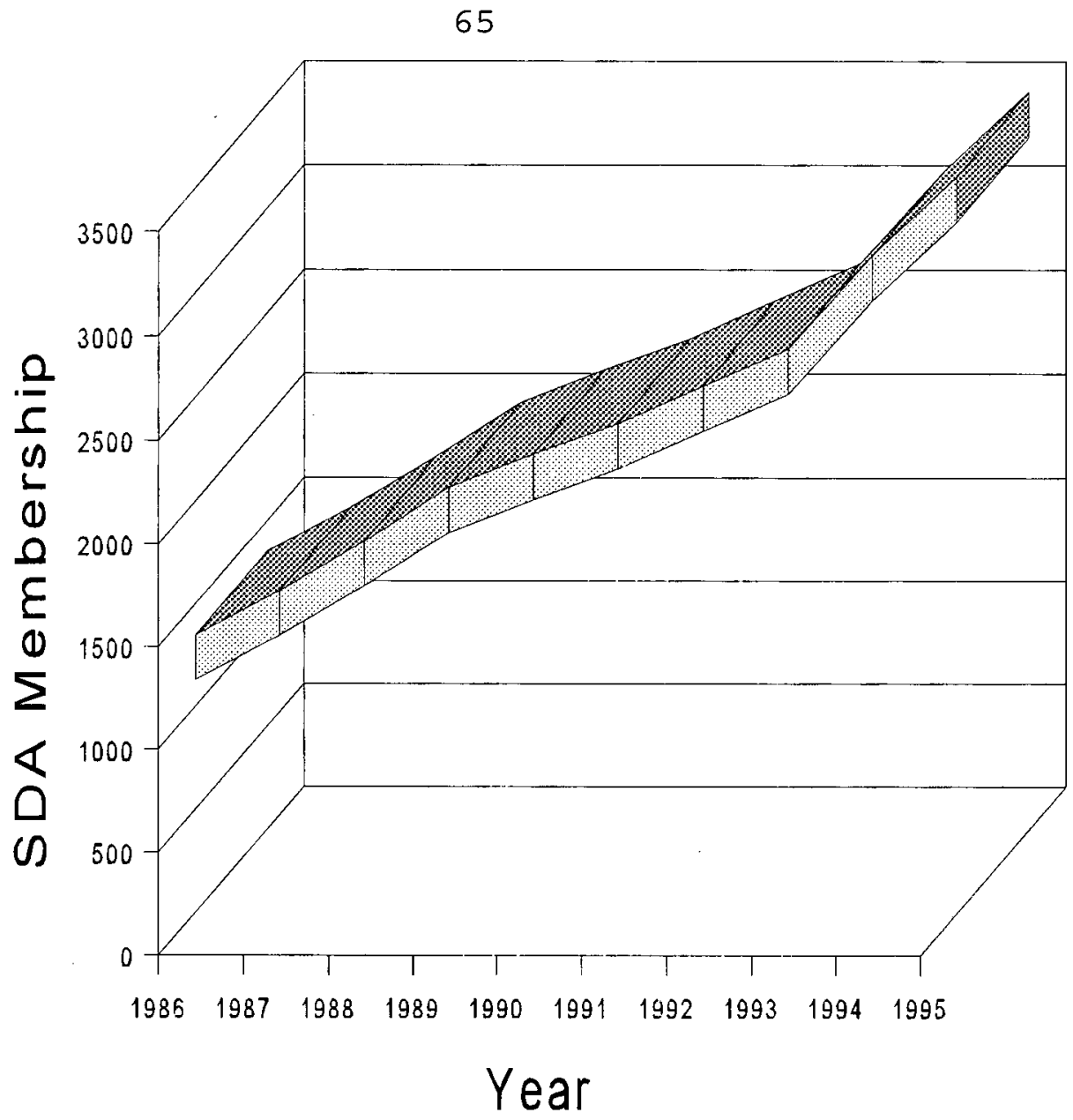

Figure 1. Membership per year.

TABLE 1

MEMBERSHIP GROWTH OF BOTH ENGLISH AND SPANISH CHURCHES PER YEAR

\begin{tabular}{|l|l|l|l|l|l|l|l|l|l|l|}
\hline Year & 1986 & 1987 & 1988 & 1989 & 1990 & 1991 & 1992 & 1993 & 1994 & 1995 \\
\hline $\begin{array}{l}\text { Mem- } \\
\text { bership }\end{array}$ & 1,243 & 1,458 & 1,701 & 1,961 & 2,121 & 2,267 & 2,450 & 2,628 & 3,074 & 3,451 \\
\hline
\end{tabular}




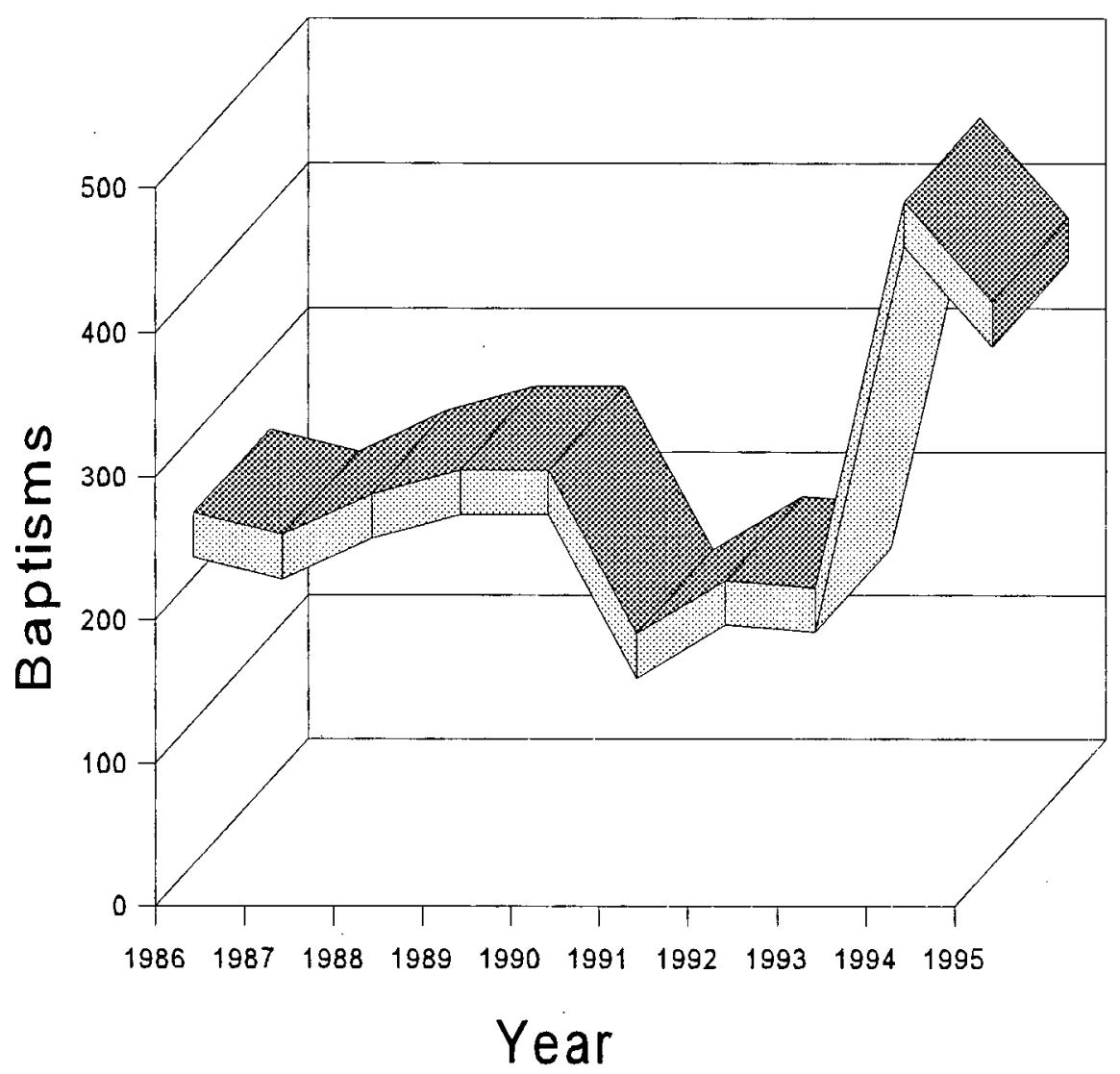

Figure 2. Number of baptisms per year.

TABLE 2

NUMBER OF BAPTISMS PER YEAR FOR BAY ISLANDS

\begin{tabular}{|l|c|c|c|c|c|c|c|c|c|}
\hline 1986 & 1987 & 1988 & 1989 & 1990 & 1991 & 1992 & 1993 & 1994 & 1995 \\
\hline 230 & 215 & 243 & 260 & 160 & 146 & 183 & 178 & 446 & 377 \\
\hline
\end{tabular}




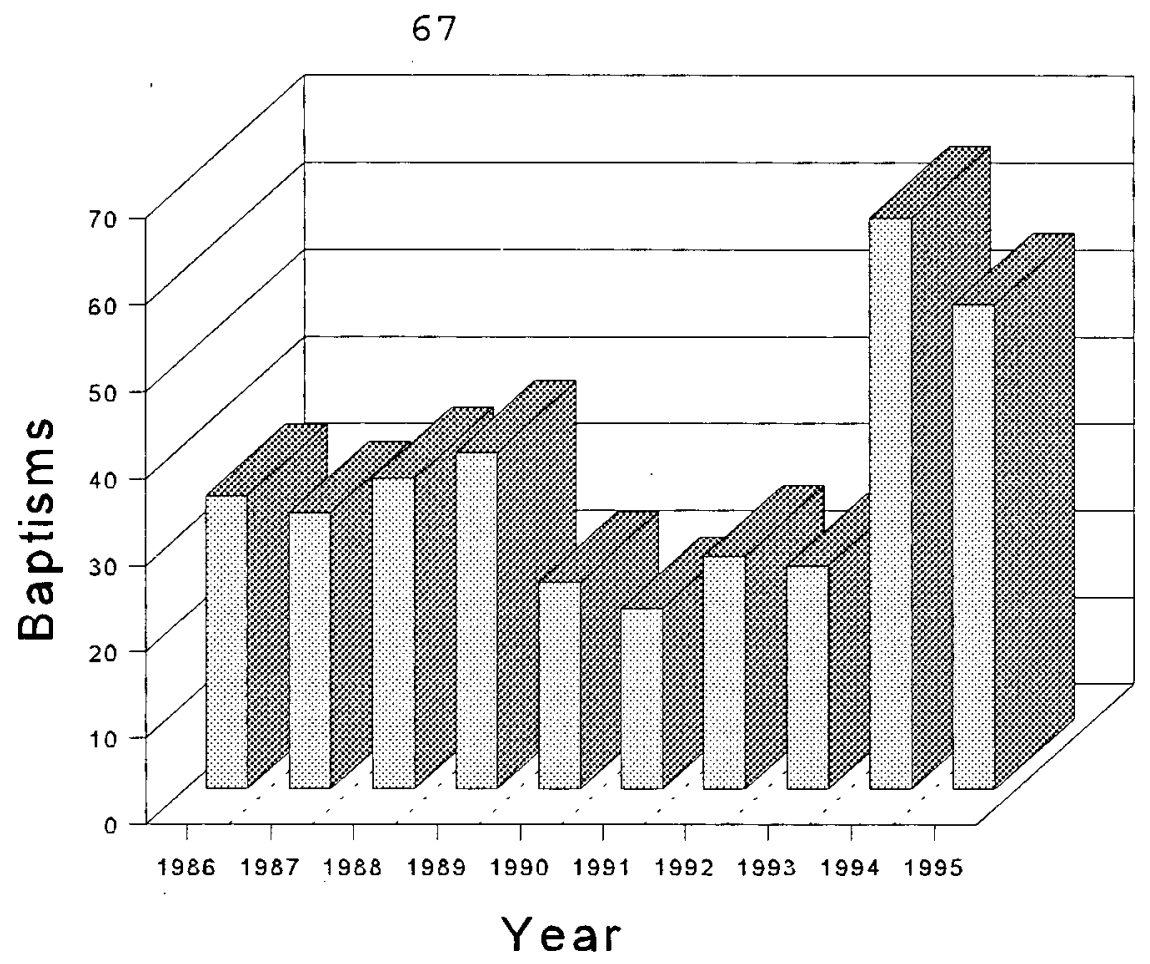

Figure 3. English baptisms per year.

TABLE 3

ENGLISH BAPTISMS PER YEAR

\begin{tabular}{|r|r|r|r|r|r|r|r|r|r|}
\hline 1986 & 1987 & 1988 & 1989 & 1990 & 1991 & 1992 & 1993 & 1994 & 1995 \\
\hline 34 & 32 & 36 & 39 & 24 & 21 & 27 & 26 & 66 & 56 \\
\hline
\end{tabular}




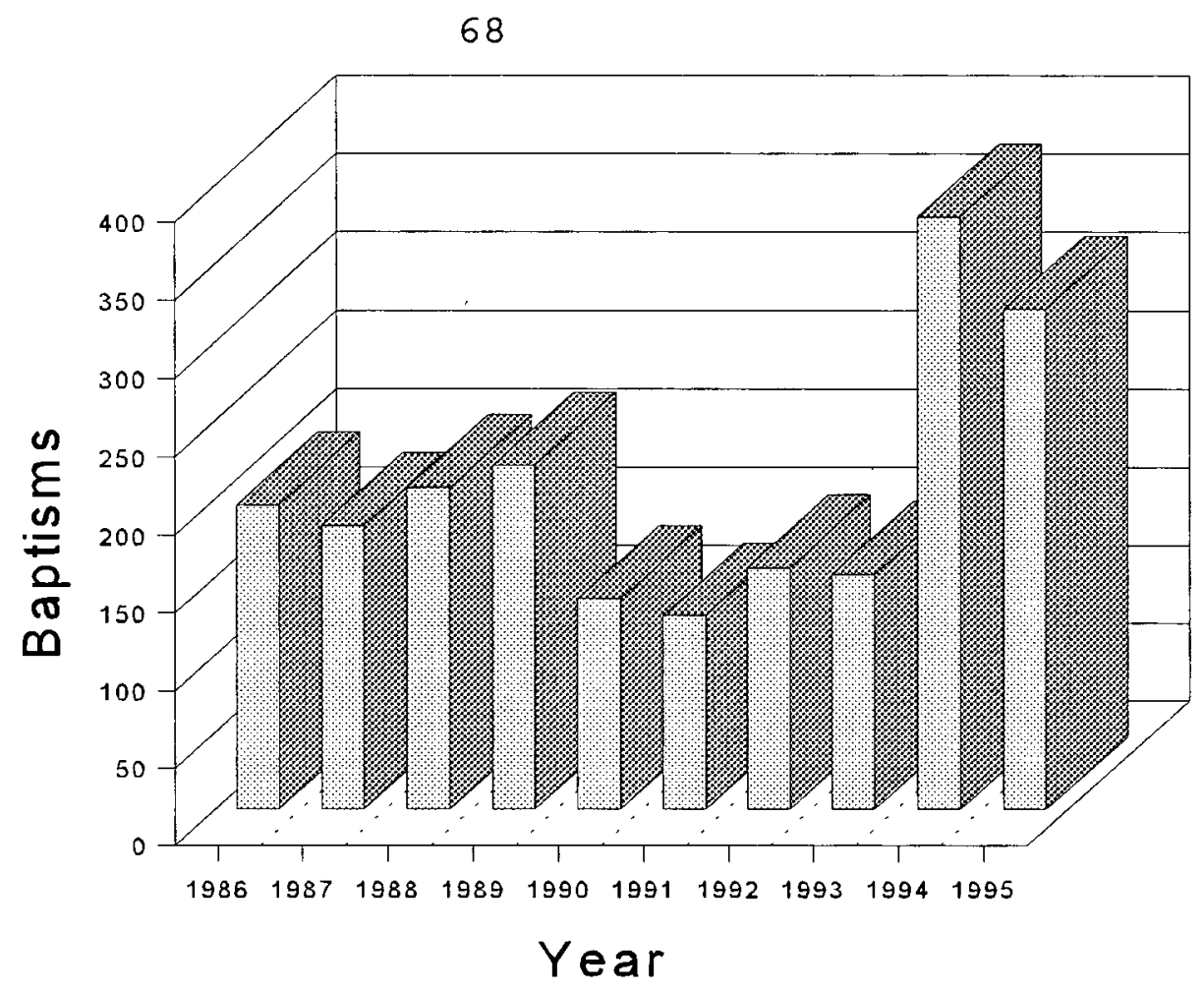

Figure 4. Spanish baptisms per year.

TABLE 4

SPANISH BAPTISMS PER YEAR

\begin{tabular}{|c|c|c|c|c|c|c|c|c|c|}
\hline 1986 & 1987 & 1988 & 1989 & 1990 & 1991 & 1992 & 1993 & 1994 & 1995 \\
\hline 196 & 183 & 207 & 221 & 136 & 125 & 156 & 152 & 380 & 321 \\
\hline
\end{tabular}




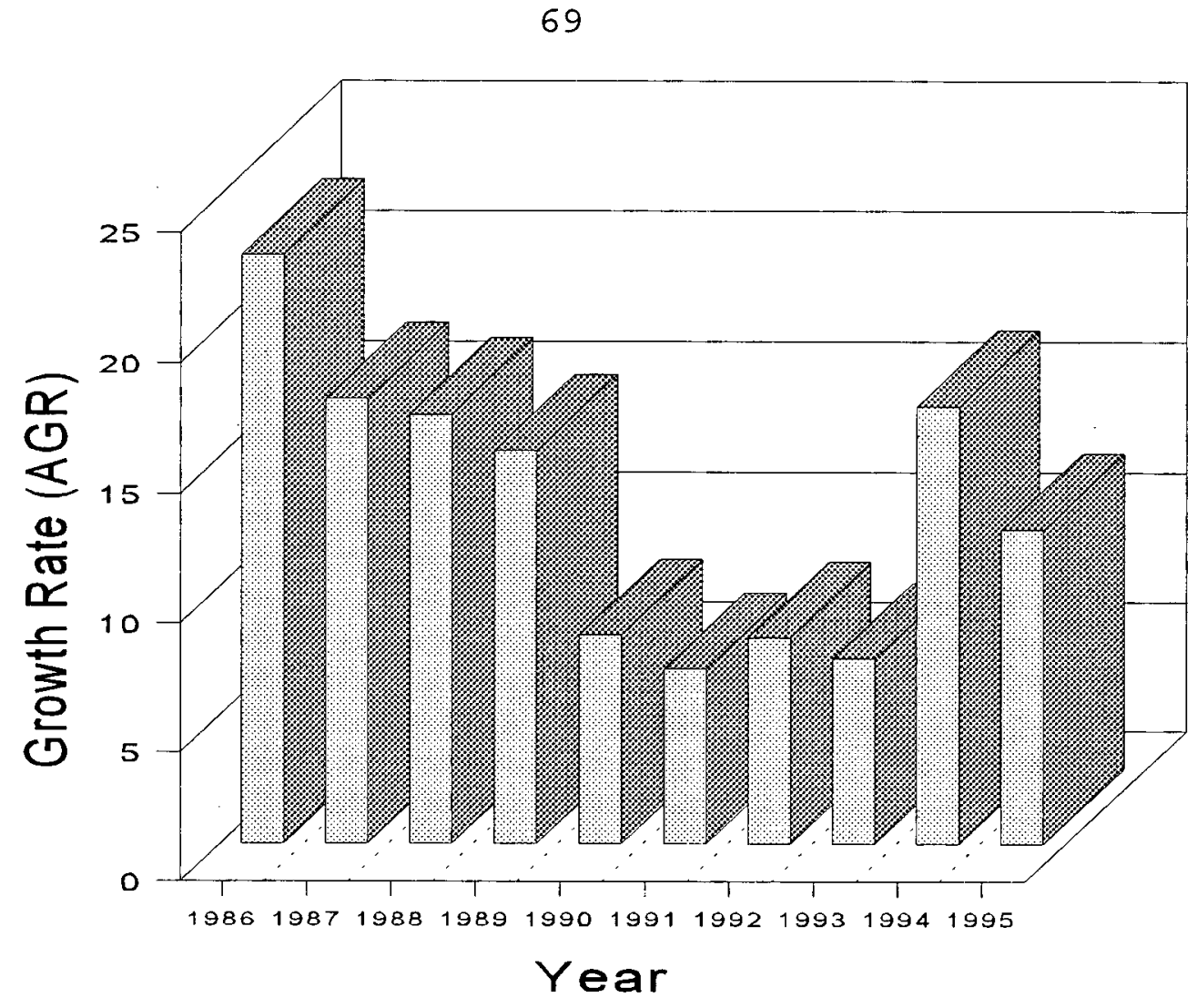

Figure 5. English and Spanish annual growth rate (AGR).

TABLE 5

PERCENTAGE OF AGR PER YEAR

\begin{tabular}{|l|l|l|l|l|l|l|l|l|l|}
\hline 1986 & 1987 & 1988 & 1989 & 1990 & 1991 & 1992 & 1993 & 1994 & 1995 \\
\hline 22.7 & 17.2 & 16.6 & 15.2 & 8.1 & 6.8 & 8.0 & 7.2 & 16.9 & 12.2 \\
\hline
\end{tabular}




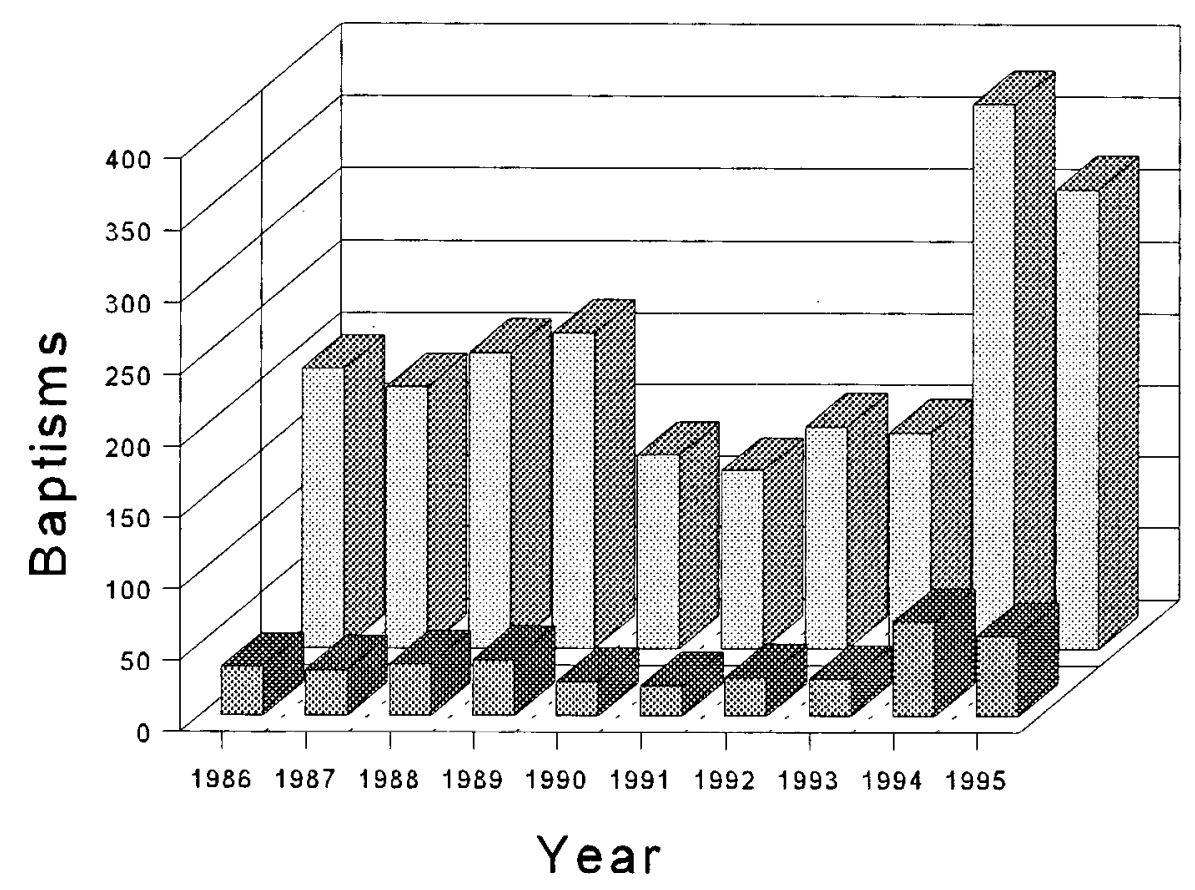

\% Spanish \% English

Figure 6. Comparison of Spanish and English baptisms 1986-95.

TABLE 6

A COMPARISON OF SPANISH AND ENGLISH BAPTISMS 1986-95

\begin{tabular}{|l|l|l|l|l|l|l|l|l|l|l|l|}
\hline 1 & Year & 1986 & 1987 & 1988 & 1989 & 1990 & 1991 & 1992 & 1993 & 1994 & 1995 \\
\hline 2 & English & 34 & 32 & 36 & 39 & 24 & 21 & 27 & 26 & 66 & 56 \\
\hline 3 & Spanish & 196 & 183 & 207 & 221 & 136 & 125 & 156 & 152 & 380 & 321 \\
\hline
\end{tabular}


In 1988-1989, there was a small increase in baptisms in the English churches due to the fact that great emphasis was placed on public evangelism (see fig. 3). Notwithstanding, only about 5 percent of all those baptized remain in the church. This was due in part to the lack of a follow-up plan implemented by the mission. During the years of 1990-1992, there was an overall decline in baptism. The reason attributed to the decline in baptisms is because of the problems of administration and situations of immorality that created uncertainty in the church. There was a serious problem of clandestine behavior between the president and a member of the church. In addition, during this time, a few pastors were involved in immoral practices. Because of these problems 1990-1992 were difficult years with the church also actually experiencing decline in attendance.

These figures also indicate that phenomenal growth occurred during 1994 (see fig. 6). This was attributed to several factors: first, change in administration, and second, an Island-wide plan of evangelism. ${ }^{1}$ During this

1 "Mega Bay Islands" was the term used for the evangelistic trust for the year 1994. The purpose was to hold a major evangelistic meeting in every major district on the Islands. 
period, however, the English churches experienced a little growth. And third, there was a positive reaction to the fairly new pastors and administration. The events of 1994 were able to rebuild confidence among church members after the sad events of the early 1990s.

The figures in the above tables also indicate a decline from 1994 to 1995, but in comparison to the years prior to 1994, 1995 still showed an increase of over one hundred members' with both English and Spanish churches experiencing growth. In 1994 one new Spanish Church was established. These figures and tables, vividly illustrates that something must be done to evangelize the English communities of the Bay Islands.

\section{Analysis of Growth Among the English- Speaking Churches of the Bay Islands}

During the seventies and eighties, the SDA church was faced with a crisis. There were several churches and schools but no one to coordinate or manage the institutions. The Adventist Mission of Honduras, which was the coordinator of all the work on the Islands, was interested in the financial support they received from the Bay Islands but not in the 
work itself. The greater part of the Honduras Mission budget came from the Bay Islands, but the mission provided two and sometimes only one pastor to coordinate the work. The Islanders were not happy with that situation and thought about the establishment of a Mission on the Islands. This was granted, and in 1986 a Mission was formed, but not without problems.

Even with their own Mission, the expectations of the Islanders were not met. In fact, the situation became even worse. The leaders, departmental directors, and pastors who were sent by the Union were not culturally compatible. Many spoke only broken English, with most evangelistic efforts focused on drawing Spanish-speakers and the poorer classes to the church. English material was rarely available, and little emphasis was placed on the needs of the Englishspeaking people.

The quality of leadership and lack of trained pastors led to many problems in the English-speaking churches.

1. Churches were without trained pastors.

2. Pastors and churches failed to provide follow-up programs .

3. Members were without any true knowledge of the SDA 
doctrines.

4. Churches became weak, unhealthy, and dormant.

5. Tithes and offerings decreased.

6. Members became uncooperative.

7. Many pastors spent only one or two years in a district.

8. The Union sent Spanish-speaking pastors as district pastors of English churches.

9. The local Mission committee was made up of 95 percent foreign workers.

10. The schools of the Bay Islands were not only understaffed but the leadership and the problem of poorly qualified teachers was also troubling.

11. Because of the problems involving leadership and pastoral support, financial support for the mission declined.

12. Bay Islands departmental leaders implemented methods of evangelism that were used to evangelize Catholics, whereas the Bay Island people are predominantly Protestants.

13. Policy changes made by the Mission committee, which was composed largely of foreigners, caused the local 
members to further distrust the mission because so many decisions were not relevant and did not match the needs of the community.

The rapid development and economic growth, in the Bay Islands have produced drastic changes in the structure of society. These changes have had a dramatic impact on the struggling Bay Islands Mission, and have caused many personal, social, and psychological problems for the workers and members of the church.

\section{Conclusion}

One can see that the Bay Islands Mission has failed to develop a plan for church growth that would evangelize the English-speaking people of the Bay Islands. The challenge and the responsibility remain for the Bay Islands Mission to reach the expanding population during this period of opportunity. Chapter 5 proposes a workable strategy for reaching the English-speakers of the Bay Islands of Honduras. 
CHAPTER 5

A STRATEGY TO REACH THE ENGLISH SPEAKERS

OF THE BAY ISLANDS OF HONDURAS

\section{Introduction}

In chapter 4 we saw that in recent years evangelism has been ineffective in the English-speaking churches. There have been no plans or programs to meet the secular-minded Bay Islander with the intention to evangelize them. Increased emphasis on strengthening the existing churches and developing new congregations must become a priority for the Bay Islands English-speaking churches.

Considering that church planting is the supreme task of the church, ${ }^{1}$ and is "the most effective evangelistic methodology known under heaven," ${ }^{2}$ it must become the priority of the Bay Islands Mission.

${ }^{1}$ McGavran, Understanding Church Growth, 41.

${ }^{2}$ Peter C. Wagner, Strategies for Church Growth, (Wentura, CA: Gospel Light Publications, 1976), 16. 
The question is, are there methods that could be employed or bridges used to accomplish this task? I feel that there are. Bill Hull says that "the best way and the right way to grow a church is to improve the members' penetration ability. Target an unreached group, develop a plan, recruit personnel, and go for it."1 Therefore, this chapter suggests ways in which the English churches can reach the English-speakers of the Bay Islands.

If the SDA church of the Bay Islands is to reach the English-speakers, emphasis needs to be placed upon three important elements:

1. Bold plans. McGavran reminds us that "church growth seldom comes without bold plans."2 New strategies and methods must be employed if the people of the Islands are to be reached.

2. Vision statement. When a Christian member properly articulates a vision statement, George Barna says, "It increases their confidence, satisfactorily addresses

${ }^{1}$ Bill Hull, The Disciple-Making Pastor (Tarrytown, NY: Fleming H. Revell Company, 1988), 204.

${ }^{2}$ McGavran, The Bridges of God, 437 . 
existing concerns and instills a feeling of excitement and anticipation." 1

3. Visionary leaders. Visionary leaders are the key people in determining whether a strategy succeeds or even begins. ${ }^{2}$ They are the principle people in a successful church strategy ${ }^{3}$

In our endeavor to reach the English-speaking people of the Bay Islands we need to meet the people where they are, and find out how we can meet the needs they have. Their felt needs must become our entering wedge. We can get their attention and awaken a desire only as we minister to their identified felt needs. ${ }^{4}$

\section{Points of Contact}

Points of contact can provide the opportunity for group experiences that meet fundamental human needs. According to Gisela, "next to the biological necessities, man's deepest

${ }^{1}$ George Barna, The Power of Vision (Ventura, CA: Regal Books, 1992), 54 .

${ }^{2} \mathrm{Hull}$,

${ }^{3}$ Peter C. Wagner, Church Planting for a Greater Harvest, (Ventura, CA: Gospel Light Publications, 1990), 51.

${ }^{4}$ Marlene D. Lefever, Creative Teaching Methods (Elgin, IL: David C. Cook Publishing Co., 1986), 224. 
longings are to love and to be important--important to someone." Dr. Gisela points out that this important need can be met through a healthy group life. ${ }^{1}$ Through personal contact, an individual can develop respect and understanding for others and a recognition of others in the society. This is the purpose of making contact with the people in the community in which we live.

Points of contact will build human relations and develop a genuine contact between members of the church and those of the community. In this way, members of the church are more able to minister to the felt needs of community members. In meeting people of the community on a daily basis, they will understand their concerns and needs. Because of this, their contacts, interests, and enthusiasms will be vital, thoroughly sincere, and sympathetic. If this method must work, however, members of the local church must be introduce to the Savior's method, build them to maturity, and train them to eventually spiritually reproduce and be effective for Christ. It is to encourage all who are a part of Christ's church to imitate the character of Christ so

${ }^{1} \mathrm{Gisela}$ Konopka, Social Group Work, a Helping Process (Englewood Cliffs, NJ: Prentice-Hall, 1963), 39-40. 
that they can begin to mature and employ their gifts in the mission of the church and to fulfill their calling in life. When this is achieved, members of the church will be able to talk about spiritual topics to their friends whom they seek to sàve.

\section{Bay Islands Youth Outreach}

The purpose of this activity is to get the SDA youth from the Islands involved in sharing their talents in

different outreach programs or projects. The development and implementation of an activity or program for this age group depends primarily on what the individuals themselves want to do. Learning an individual's interests is key to keeping the program effective.

Young people will be given the opportunity to participate in programs around the Islands such as drug prevention programs, evangelistic meetings, youth seminars, intra-mural programs, etc. The purpose of such an outreach program will be to make contact with all classes of young people, even those who are hostile to religion. The activities will be led by the youth, supported by the church and adult sponsors. 
Some of the outreach programs could be:

1. Peer Prevention programs

2. Intramural programs

3. Community programs

4. Vacation Bible schools.

\section{Peer Prevention Programs}

The goal of this contact program will be to help other young people become alcohol-, tobacco-, and drug-free. This program can be done through friendship groups consisting of small groups where discussions are led by a youth leader and supervised by an adult. All meetings should begin and close with prayer.

A special meeting, or conference will be used to recruit new members. In the meeting the youth will be invited to make a commitment to live drug-free. 1

Special conferences will be held to teach the participants about the effects of drugs, alcohol, and tobacco. During these meetings each participant will receive

${ }^{1}$ Guidelines for this program will be taken from the program Adventist Youth to Youth. Patricia B. Mutch, Adventist Youth to Youth (Berrien Springs, MI: Institute for Prevention of Addictions, Andrews University, 1995). 
training to help them learn new skills in outreach and leadership. Such workshops can be called, "Action planning," "How to do it workshops," or "Leadership training seminar." The focus will be on positive alternatives to handling problems of drugs, alcohol, and tobacco, which will be seen as unnecessary and harmful. Participants will be asked to make a personal commitment to abstain from all types of drugs.

When seminar participants become interested in the program, they will be given an invitation to make a personal commitment to live without the use of alcohol, tobacco, and drugs. No one, however, will be expected to make a commitment before he or she can attend a seminar. Once a person decides he or she wants to be part of the group, he or she will be asked to sign a pledge.

These groups will be encouraged to share their experience by going to other churches and also traveling to other islands. The presentation of their experience and talents may be shared in the following manner:

1. Drama team: Performances that portray drug issues through dramatic skits, games, and talks.

2. Social events: Parties, picnics, outings, games, 
etc. This will be for group enjoyment or fund-raising purpose.

3. Youth seminars: Young people giving talks, participating in round-table discussions, and sharing personal experiences.

\section{Intramural Programs}

Intramural sports programs could include the following: football, basketball, volleyball, and baseball. Because of time and space, I use football as an example.

Each team should be formed with one-half of the players being SDA and the other half non-SDA.

Many important personal and social values and outcomes can be achieved from participation in sports. Players can learn to play according to the rules, accept boundaries, develop new skills and interests, accept defeat as well as victory in good spirit, and cooperate with others.

A well-arranged schedule of games will serve as a direct stimulus to the development of a loyal team spirit, and offer healthful recreation and an enjoyable contact between SDA youth and non-SDA youth. Youth of all ages have a need for social recreation. 
And while this is not the whole purpose for recreation, it will provide a time where the youth can come aside and share experiences and give support to one another. Appropriate spiritual activities such as prayer and short Bible studies should be part of any sport program. In addition, the nonSDA youth should be constantly invited and encouraged to join other youth activities sponsored by the local churches.

\section{Community Programs}

Community service programs will be started with the intention of establishing favorable relationships with government and public service personnel. Such programs will also provide the SDA members of the service groups direct contact with all classes of people, and will help develop relationships and good favor with the people of the community .

Some of the activities that could be sponsored include:

1. Plant-a-tree-day: A Plant-a-tree-day should be dedicated to planting trees in the parks or forests that have been affected by severe weather.

2. Community clean-up day. Clean-up-day activity would involve cleaning up rivers, parks, or trashy areas in 
various communities.

All activities should be adapted to the needs of the community and abilities of the participants. The imagination and ingenuity of each activity leader are important elements, but it must be stressed that the needs and interests of the community should dictate the type of activities offered.

No one should be required to have advanced preparation to participate in these social activities. Participants should be able to use whatever skills they have, with any emphasis on specialized skills minimized. Group fun and enjoyment are far more important.

Besides actually doing the community service work, each community awareness day should include talks, speeches, and programs held in the parks, auditoriums, or schools that educate and emphasize the need for a clean community.

Before the volunteers engage in any activity, the group could meet in a special place for instructions, announcements, and prayer. During this time a short devotion could be given. At the end of the day's activities, all members should meet again to hear words of appreciation and to receive recognition for their contribution to the 
community.

Activities of this type could be done as often as once or twice a month. Volunteers could meet once a week to plan and organize the events, with the weekly meetings including a time for Bible study and prayer.

Vacation Bible School (VBS)

A yearly VBS could be organized by the church for the children of the community. Classes could be held in the school or at the church. This program would also provide an additional point of contact between the SDAs and the children and parents of the community.

A VBS provides direct contact with parents and children and offers another means of introducing non-believers to Jesus Christ. Imagination, planning, and organizational ingenuity combined with enthusiastic leadership can produce an exciting and stimulating program that will keep children returning to the VBS activities.

of major importance to any successful program is what happens to each and every boy and girl who is involved with the program. The leaders should always remember that their activities are not an end in themselves. They are merely the 
tools with which many wholesome aims and objectives can be reached. Besides making contact with the neighborhood children, an additional purpose of the program is to introduce each child to christ. Therefore, each day's program will be developed to help the children learn songs of praise and to deepen their understanding and love of Christ.

\section{Contact Seminars}

New Problems and challenges demand new methods and strategies. Those who seek perfection often forbid innovation and change, because it introduces too many unknowns. Improvements and a move towards perfection can only be obtained through the lessons taught by mistakes. One question, of no minor importance, therefore, is this: should the new challenges of today also be marked by new methods and approaches in the advancements of the gospel? We cannot close our eyes to the fact of a growing dissatisfaction and ineffectiveness of some methods, long in use. Many old ways must give place to something different. Without presuming to pronounce upon the past methods as unreasonable, or the change as ultimate, all honest plans 
should have a fair trial. In any case nothing is gained by repression. Therefore, it is not well to hang on to any system, evangelistic or administrative that is no longer effective, or unfitted to fulfill present needs. Contact seminars, therefore, have as their purpose the placing of SDA church members in contact with the people of the community. The church of the Bay Islands has been separated too long from the community in which it exists. If the church is to make any change whatsoever in secular society, it must find ways to make contact with the people whom it seeks to reach.

\section{Attraction Seminar}

The purpose of a contact seminar is to meet the Bay Islanders in an atmosphere where personal relationships and confidence can grow. Contact seminars will be used to answer real life problems while developing trust and friendships.

Two possible contact or felt-need seminars. ${ }^{1}$ that could

${ }^{1}$ For the purpose of this project, these seminars are not developed anew in this project, I would recommend the already-prepared seminar materials that are available in Adventist Book Centers. Other seminars that could be used are: Marriage seminars, sex and marriage, a 12 -step program, a financial management program, etc. 
be used as an entering wedge are Breath-free and stressreduction seminars. By offering such felt-need seminars, the SDA church on the Islands will become a place where the middle-class Islanders could turn for help, rather than turning to spiritualist or psychic mediums, which are gaining ground on the Islands. These seminars are intended to help create confidence and friendship between Bay Islands SDA Christians and the middle class.

\section{Bridge Seminars}

Seminars in a second phase, the bridge seminars, should help provide a link between peoples' physical felt needs and spiritual needs. Two suggested bridge seminars could be family wellness and positive parenting.

Bridge seminars should help the participants consider spiritual answers to life's questions. ${ }^{1}$ The seminars are also intended to help the Bay Islands SDA members become involved in meeting people and people's needs while

${ }^{1}$ I suggest that the person giving the seminar acquire the already-prepared materials and use them. These materials can be obtained through the local conferences. The purpose of this dissertation is not to prepare new seminar materials but suggest the ways to reach the English-speakers of the Bay Islands. I am also suggesting the order of using the prepared materials. 
presenting solutions that will last forever. Christ must be presented as the center of family life in these seminars and as the key to happy families. By this time the Bay Islands' members should feel more comfortable in meeting people at a point of interest. By meeting the peoples' needs, they can be led a step closer to Christ. The task of these seminars is simply to help people move from their present concerns to ultimate concerns, helping them realize that positive solutions to their family problems are found in Christ.

\section{Response Seminars}

Having established friendships and built confidence, the next step will be to conduct response seminars in order to help the Bay Islanders move a step closer to Christ. Because so many people do not have a Christian background, the first of these seminars should be nondoctrinal in its approach. It is only when Christ has been accepted as a personal savior that SDA doctrines should be taught. Bascom states that "when people accept doctrinal and prophetic truth before accepting Christ, they have a new set of 
opinions, but their hearts remain unchanged."1 Possible topics could include: "Handling discouragement," "How do I know God's will?" "How can I study the Bible?" "The power of personal faith," and Learning how to pray."

These seminars should blend the daily felt needs of the envitees with the answers presented in Scripture and should show them, step by step, how to accept Christ.

Every session should close with a short devotional related to the topic of the seminar session. This is not a time for doctrinal lessons, but rather an opportunity to illustrate how the loving truths of God apply to the enrichment of one's life and are relevant to the needs of modern people.

Doctrinal Seminars

Once friendships have been established through the contact and bridge seminars, Daniel and the Revelation seminars could be introduced. By this time confidence should

${ }^{1}$ Maurice Bascom, Adult Sabbath School Lessons: Biblical Models of Soul Winning (Silver Spring, MD: Department of Church Ministries, General Conference of SDA, 1994), 41. 
have been developed and the envitees should be prepared to listen to deeper biblical messages. It is only when Christ has been accepted as Savior that SDA doctrine will become meaningful and acceptable. It is imperative that our new friends find Christ and love Him before they are introduced to doctrines.

After friendships have been established through the felt needs and bridge seminars, our new friends should have confidence in the church's ability to provide answers to their doctrinal questions. Doctrinal seminars provide opportunities to answer the spiritual questions people have.

\section{Conclusion}

For church growth to become a dynamic process, the local church must play the key role. Karl Barth states, "First and supremely it is God who exists for the world. And since the community of Jesus Christ exists first and supremely for God, it has no option but in its own manner and place to exist for the world."1 One of the indispensable forms of ministry in the local church is building

${ }^{1}$ Karl Barth, "The Community for the World," in Theological Foundations for Ministry, ed. Ray S. Anderson (Grand Rapids: Eerdmans, 1979), 499. 
relationships and ministering within the local community. ${ }^{1}$ Ministry in all its forms must became a way of life if the church is to grow or even survive. The church's mission, then, authenticates its place in the world. Through its participation with the world and its service for the world it can meaningfully enter into the process of taking the gospel into the world. Ultimately a healthy church must gave birth to new churches.

If the local church is to reflect the apostolic church, then the entire membership must be involved in ministry. The church must be a friendly and loving community. It must be a place where all people will feel loved, appreciated and accepted. That ministry can take many forms. It can be general or specific, doctrinal or involve secular activities, but if the members of the church fail to fully participate in the mission of the church, the church fails to be what it exists for. Each member has a vital role to play in the church and in the community. The church of the Bay Islands must come to realize that only after it has

${ }^{1}$ Gene A. Getz, Sharpening the Focus of the Church (Chicago: Moody Press, 1974), 31-36. 
successfully made contact with the people in their communities will the traditional forms of evangelism be successful. 
SUMMARY， RECOMMENDATIONS， CONCLUSIONS

\section{Summary}

The Seventh-day Adventist message entered Central America as early as the late 1870 s when Elizabeth Gauterau began to send Christian literature to her family and friends in the Bay Islands. In 1885 with Elizabeth's arrival on the Bay Islands of Roatan, the SDA church grew and expanded until Hutchins, a minister from the U.S., was sent to the Bay Islands to organize the church and strengthen the new work.

For many years the SDA church was faced with many problems. Several churches and schools were begun, but there was no one to coordinate these institutions. The Islanders were not happy with the situation and thought about the establishment of a mission. This was granted, and in 1986 the Bay Islands Mission was organized but not without a multiplicity of problems. Leaders, departmental directors, 
and pastors employed on the Bay Islands are not culturally compatible. Many speak only broken English and, therefore, are unable to effectively minister to the needs of the English-speaking people.

The quality of leadership and lack of English pastors has led to many problem in the English-speaking churches. Adding to the problem, English materials are rarely available, evangelistic methods are not effective, and little emphasis is placed on the needs of the Englishspeaking churches. What is even more tragic is that the veracity of these statements has been proven in application. There has not been one new English-speaking church established in the Bay Islands over the last two decades, and some of the churches are experiencing membership declines and could possibly be closed in the future. The SDA church has not only failed to gain as a percentage of the population and to increase the number of churches, but it has failed to even keep pace with the general population growth of the Islands, so that today there are only ten English churches for every four thousand persons in the Bay Islands. Presently the SDA church does not even have as many church members or as many churches 
organized per thousand population as it had in 1900.

\section{Recommendations}

I am convinced that if the Bay Island churches adopt new methods of evangelism, church renewal and revitalization will result. No matter what the churches decide to do, it is important that every church does something to make disciples. Lawrence Richards points out:

The making of disciples is an interpersonal and transactional process, involving teacher and learner in a wide range of real life experiences. The support and nurture of God's life within seems to require a life-context, a model from whom those being discipled can learn, and a transactional relationship between persons. ${ }^{1}$

The church must implement some plan to move people from merely sitting in the pews Sabbath after Sabbath, to participating in the fulfillment of the great command to go and teach all people. I recommend:

1. Church growth, in all its forms, should be taught to the Bay Islands' mission leaders and pastors. Church growth skills will improve each pastor's and leader's capabilities for mission outreach as each works within the framework of

\footnotetext{
${ }^{1}$ Lawrence O. Richards, Christian Education (Grand Rapids, MI: Zondervan Publishing House, 1975), 32.
} 
their spiritual gifts.

Since it is natural to resist change, the programs, as presented in this project, can become successful only through an educational process. Leaders and members of the churches must all be educated regarding the need and value of innovative outreach programs.

2. More flexibility in evangelistic methods should be encouraged. There is not enough elasticity; there is undue conservatism and reluctance to learn new lessons; there is attachment to stereotyped forms that have the odor of antiquity. The pace of life in the Islands is changing so rapid that what worked ten years ago often has no impact at all today. SDA evangelistic methods have remained unchanged since the nineteenth century. It is time to try some new approaches.

3. The Bay Islands Mission must employ well-trained English leaders and pastors. This move will not be easy, recognizing that these workers will have to be acquired with a great deal of expense, but it will pay off in the long run.

4. The Union and Mission should be encouraged to change their autocratic management style. Undue use of arbitrary 
power, is too often wielded by the Union committee; undue authority is sometimes lodged in one person. Issues, affecting scores of intelligent, able, and devoted laborers in the field, who know the needs and conditions of the work as no one else can, are too often decided by a Union committee whose members do not know English-speaking culture and customs of the Bay Islands. Bay Island Englishspeaking Adventist must be integrated into the boards and committees at both the Union and Mission level if confidence is to be restored and financial backing increased.

5. Pastors should stress that each member has a personal responsibility to become involved in seeking the salvation of others. Pastors must become visionary motivators and trainers so that the laity will become involved in missionary work.

6. The church should become an equipping center where the members of the church can be trained. Ellen G. White reminds us that part of the minister's work is to keep the church alive by teaching its members how to labor with him for the conversion of sinners. This is good generalship; and the result will be found far better than if he should seek to perform 
the work alone. ${ }^{1}$

7. Ministers and the laity should plan wisely, as faithful stewards. They should not hover over churches already organized but should do aggressive evangelistic work, teaching the word of God and doing house-to-house evangelism in places that have not yet heard the truth.

8. A church-growth task force should be establish with laity, mission leaders, and pastors as members. This task force should be responsible to

a. Develop English Materials

b. Raise finances for outreach programs

c. Train laity and leaders in church growth

d. Target groups in the various communities for evangelism and outreach programs

9. The Bay Islands Mission should begin a pilot project using seminars as an evangelistic tool. The long-range objective of such a program should be to improve interpersonal relationships among the church members, improve the members' understanding of scriptures and health,

${ }^{1}$ White, 357. On pp. 122 and 123 she also states: "Let every worker in the Master's vineyard, study, plan, devise methods, to reach the people where they are." 
improve the church members' relationship with the surrounding community, and increase the membership of the church through mission outreach.

\section{Conclusion}

The local church should be considered the center where stewards are trained for extending the mission of the church. Church growth is the result of an active church which extends the good news of salvation to the world around it.

It is my hope that as these plans are implemented, that the number of English-speaking churches and the number of members double over the next seven years. It is my dream that each Adventist church become strategically located as a resource center for church growth.

For this to become a reality, however, the English churches of the Bay Islands must set priorities, goals, and objectives that can easily be translated into plans of action. Without such intentional planning, the Bay Islands' English-speaking churches will never emerge to become a people of mission.

It is my dream to see the English churches become more 
effective in evangelism, more adaptable to the methods of evangelism, better at accomplishing goals and maintaining mission purpose, and developing and changing in ways that improve effectiveness.

This dissertation, "A Strategy to Reach the EnglishSpeaking People of the Bay Islands of Honduras," challenges both the Bay Islands Mission, and pastors, in the closing years of the twentieth century, to make a reappraisal of their attitudes towards, and participation in, the growth of churches among the English-speaking people. 
APPENDIX 


\section{HOW TO CALCULATE GROWTH RATES}

Standard church growth calculations and comparisons use two rates: annual growth rates (AGR) and decadal growth rates (DGR). We will describe them one at a time.

\section{ANNUAL GROWTH RATES (AGR)}

Annual growth rates (AGR) compare the growth of the church from one successive year to another. They answer the important question: exactly how much did our church grow in a particular year? AGR is expressed in percent (\%). Annual growth rates can be either positive or negative. When they are calculated, they are then plotted on bar graphs like the one below.

There is more than one way to calculate AGR, but here is the one we recommend:

Subtract the earlier year's membership from the later year's membership. (Note: your figures must be one year apart, not more.) Divide the answer by the earlier year. Then multiply this answer by 100 (this changes the decimal to percent).

Example: A church has: $\quad 350$ members in 1978

475 members in 1979

What is the annual growth rate?

Step 1. $475-350=125$

Step 2. $125 \div 350=.357$

$(L-B) \times 100$

Step 3. $.357 \times 100=35.7 \%$ AGR

Here is how a church's AGR bar graph might look for ten years:

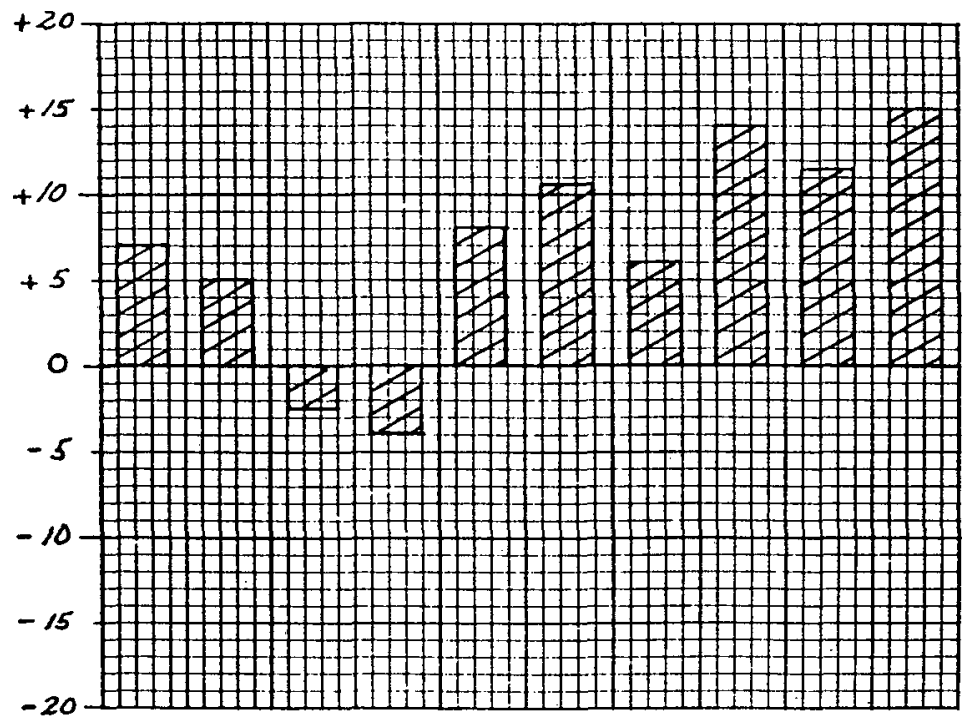

\begin{tabular}{|l|l|l|l|l|l|l|l|l|l|l|}
\hline YEAR & 1970 & 1071 & 1972 & 1975 & 978 & 1975 & 1976 & /977 & 1978 & 1979 \\
\hline
\end{tabular}

AGR $-C 1-4|+8|+10.5|+6|+14|+11.5|+15$ 


\section{HOW TO CALCULATE GROWTH RATES......}

\section{DECADAL GROWTH RATES (DGR)}

Decadal growth rates (DGR) are used for determining the rates of growth across a period of more than one year. DGR is a standard measurement that can be used not only for ten years (a decade, thus "decadal") but for two or five or 20 or any number of years. Converting growth for any period to what the growth would have been for ten years allows for ready comparision, and therefore is valuable in diagnostic efforts. You will want to master DGR calculations for use on graphs on the next few pages.

\section{A. Sample calculation for ten year period.}

When you have data that are ten years apart (such as 19691979), follow the same procedure as you did for AGR;

Example: A church has 180 members at the end of 1969 640 members at the end of 1979 (ten years)

Step 1. $640-180=460$

Step 2. $460 \div 180=2.56$.

Step 3. $2.56 \times 100=256 \%$ (DGR)

B. Calculation for other than a ten year period.

When your figures are not ten years apart, there are two ways to obtain the DGR which will convert the rate over the period of years you have to a ten-year rate, thereby enabling you to use it for comparison with other churches or with other periods for the same church. One is to use a calculator as described in paragraph C. The other is to use the appendix tables as follows:

\section{Growth Rate Tables (see appendix)}

Divide the latest year's membership by the beginning year's membership. This will give you the ratio of "latest" to "beginning" $(\mathrm{L} / \mathrm{B})$ for that number of years. Go to Table $A$ in the appendix and locate the number (or number nearest to yours) in the left hand column "L/B". Then in the column under the number of years, locate the AAGR (Average Annual Growth Rate). Now turn to Table B and locate the AAGR nearest to your AAGR. Read the corresponding DGR.

Example: A church has: 500 members at the end of 1973

700 members at the end of 1979 (six years)

Step 1. $700 \div 500=1.4$

Step 2. 1.4 on Table A for 6 years is AAGR $=5.77 \%$

Step 3. Locate $5.77 \%$ on Table B between $5.70 \%$ and $5.82 \%$.

Step 4. Read nearest listed DGR 76\%.

Note: One can see in this example the more accurate DGR would be $75 \%$. If a more precise DGR is desired follow instructions below Table B, page 39 . 


\section{Electronic calculation for other than a ten year period}

In order to do this calculation, which is more precise, you will need an electronic calculator which has the $y$ and $1 / x$ functions.

Here is how to do it. (Caution: push only the buttons indicated:)

Example:(same as manual calculation on last page): 500 in 1973

700 in 1979 (6 years)

Step 1. Clear calculator

your display
0
700
700
500
1.4
1.4
6
0.16666
1.057
1.057
10
1.752
1.752
100
175.2
100
$75.2 \%$ or $75 \%$

Step 2. 700 (latest membership)

Step 3. :

Step 4. 500 (earliest membership)

Step 5. $=\mathrm{x}$

Step 6. $\mathrm{y}^{\mathrm{x}}$

Step 7. 6 (number of 1973-1979)

Step 8. 1/x

Step 9. = ${ }_{x}$ (wait until answer shows!)

Step 10. $\mathrm{y}^{\mathrm{x}}$

Step 11. 10 (for ten years)

Step 12. = (wait until answer shows!)

Step 13. $x$

Step 14. 100

Step 15. -

Step 16. 100

Step 17. = (answer is DGR)

$75.2 \%$ or $75 \%$

NOTE: Decadal growth rates should be rounded to the nearest whole number.

\section{PRACTICE CALCULATING DGR:}

To make sure you understand the calculations for DGR, try the

following and see if you get the correct answer:

1. Simple $(10$ yrs): 350 members 1969

850 members 1979.. (answer:142\% DGR)

2. Table or 500 members 1974

electronic: 850 members 1979 ( 5 yrs)(answer:189\% DGR) (see note)

NOTE: $190 \%$ DGR is the nearest number reflected on Table B.

However, by simple calculations (interpolation) as described at bottom of Table B you can obtain a more precise DGR. 

(see Instructions below)

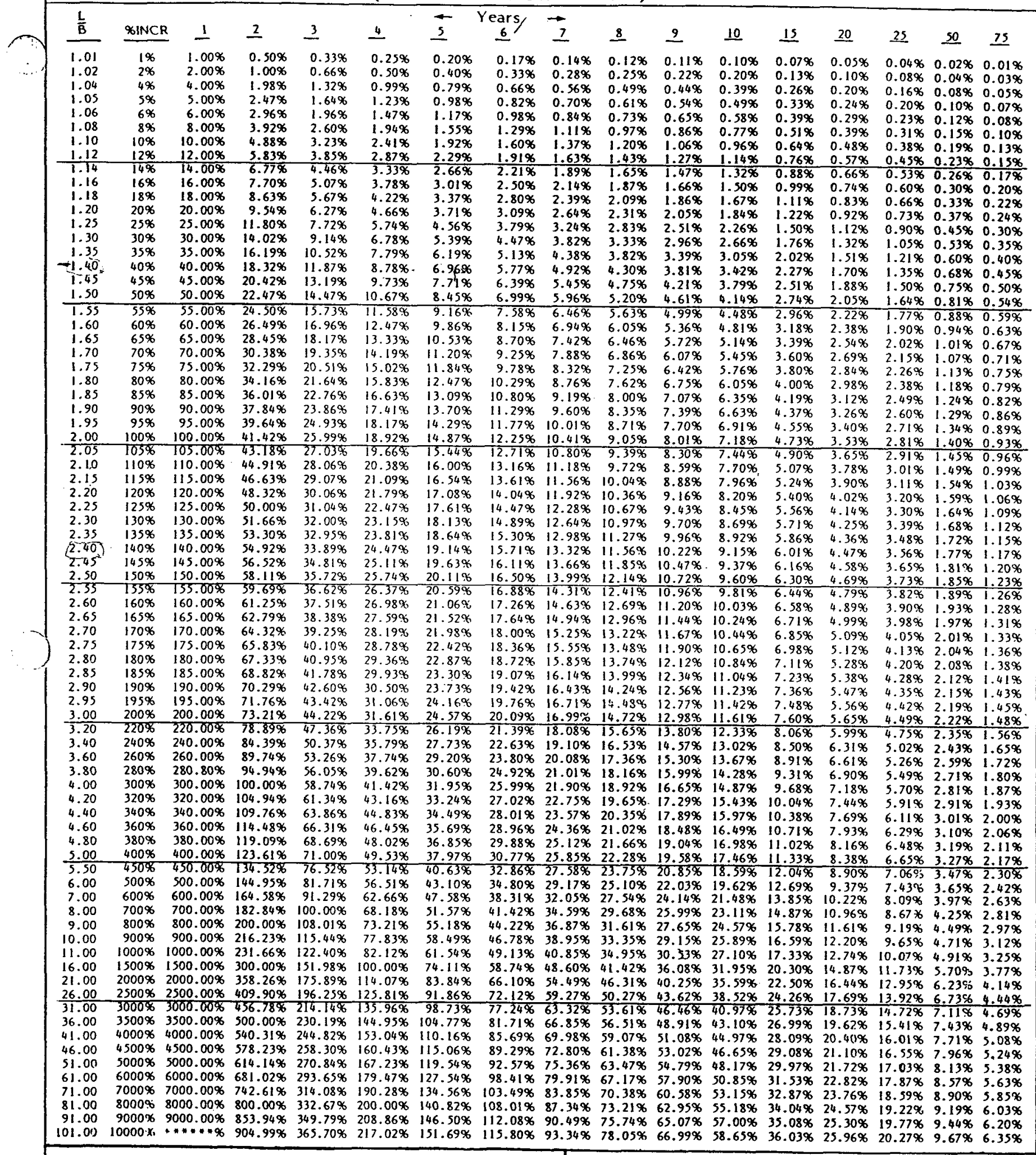

FINDING THE AAGR AND DGR

Step 1: Find AAGR by dividing members (or churches) for "latest" year by "beginning" year members (L/B). In " $L / B$ " column locate the number closest to your answer, then locate the AAGR in the appropriate year column.

Step 2: Convert AAGR to DGR by going to the 10 year column and locate the number you have for AAGR per Step 1 above (or the closest number to it). Once you've located the number, move horizontall across to the left to the "FINCR" column and read the DGR.

Note: If the exact number doesn't appear in the 10 year column, furn to Table $B$ which is an expanded 10 year column. If the exact number is there, read the corresponding DCR. If not, and you want to get
the exact number, follow the steps outlined below Table B.

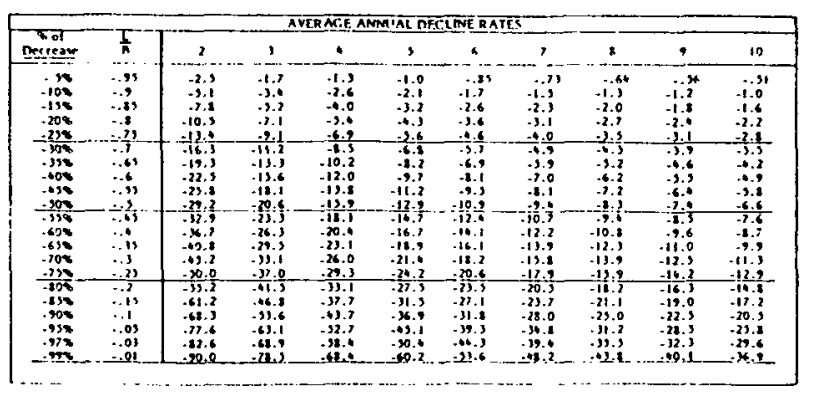




\section{DECADAL GROWTH RATE (DGR) EXPANDED 10 YEAR AAGR TABLE (see instructions below)}

\begin{tabular}{|c|c|c|c|c|c|c|c|c|c|c|c|c|c|c|c|c|c|}
\hline $\mathrm{L} / \mathrm{B}$ & AAGR & DGR & $L / B$ & AAGR & DCR & $L / B$ & AAGR & DGR & $L / B$ & $A A C R$ & DGR & $L / B$ & AAGR & DGR & $L / B$ & AAGR & DGR \\
\hline 1.01 & $.10 \%$ & $1 \%$ & 1.96 & $6.96 \%$ & $96 \%$ & 3.00 & $11.61 \%$ & $200 \%$ & 4.04 & $14.98 \%$ & $304 \%$ & 5.08 & $17.65 \%$ & $408 \%$ & 6.60 & $20.77 \%$ & $560 \%$ \\
\hline 1.02 & $.20 x$ & $2 \%$ & 1.98 & $7.07 \%$ & $98 \%$ & 3.02 & $11.69 \%$ & $202 \%$ & 4.06 & 15.0486 & $306 \%$ & 5.10 & 17.696 & $410 \%$ & 5.70 & $20.95 \%$ & $570 \%$ \\
\hline 1.03 & $.30 \%$ & $3 \%$ & 2.00 & $7.18 \%$ & $100 \%$ & 3.04 & $11.76 \%$ & $204 \%$ & 4.08 & $15.10 \%$ & $308 \%$ & 5.12 & $17.74 \%$ & $412 \%$ & 6.80 & $21.13 \%$ & $580 \%$ \\
\hline 1.04 & $.39 \%$ & $4 \%$ & 2.02 & $7.28 \%$ & $102 x$ & 3.06 & $11.83 \%$ & $206 \%$ & 4.10 & 15.1596 & $310 \%$ & 5.14 & $17.79 \%$ & $414 \%$ & 6.90 & $21.31 \%$ & $590 \%$ \\
\hline 1.05 & $.49 \%$ & $5 \%$ & 2.04 & $7.39 \%$ & $104 \%$ & 3.08 & $11.91 \%$ & 2089 & 4.12 & $15.21 \%$ & $312 \%$ & 5.16 & 17.839 & $416 \%$ & 7.00 & $21.48 \%$ & $600 \%$ \\
\hline 1.06 & $.58 \%$ & $6 \%$ & 2.06 & $7.49 \%$ & $106 x$ & 3.10 & $11.98 \%$ & $210 \%$ & 4.14 & $15.27 \%$ & $314 \%$ & 5.18 & $17.88 \%$ & $418 \%$ & 7.20 & $21.82 \%$ & $620 \%$ \\
\hline 1.07 & $.68 \%$ & $7 \%$ & 2.08 & $7.60 \%$ & $108 \%$ & 3.12 & $12.05 \%$ & $212 \%$ & 4.16 & $15.32 \%$ & $316 \%$ & 5.20 & 17.926 & $420 \%$ & 7.40 & $22.16 \%$ & $640 \%$ \\
\hline 1.08 & $.77 x$ & $8 \%$ & 2.10 & $7.70 \%$ & $110 \%$ & 3.14 & $12.12 \%$ & $214 \%$ & 4.18 & $15.38 \%$ & $318 \%$ & 5.22 & $17.97 \%$ & 42295 & 7.60 & $22.48 \%$ & 660.96 \\
\hline 1.09 & $.87 \%$ & $9 \%$ & 2.12 & $7.80 \%$ & $112 x$ & 3.16 & $12.19 \%$ & $216 \%$ & 4.20 & $15.43 \%$ & $320 \%$ & 5.24 & $18.01 \%$ & $424 x$ & 7.80 & $22.80 \%$ & $680 \%$ \\
\hline 1.10 & $.96 \%$ & $10 \%$ & 2.14 & $7.90 \%$ & $114 \%$ & 3.18 & $12.26 \%$ & $218 \%$ & 4.22 & $15.49 \%$ & $322 \%$ & 5.26 & $18.06 \%$ & $426 \%$ & 8.00 & 23.11 & $700 \%$ \\
\hline 1.12 & $1.14 \%$ & $12 \%$ & 2.16 & $8.01 \%$ & $116 \%$ & 3.20 & $12.33 \%$ & $220 x$ & 4.24 & $15.54 \%$ & $324 \%$ & 5.28 & $18.10 \%$ & $428 \%$ & 8.20 & 23.429 & $720 \%$ \\
\hline 1.14 & $1.32 \%$ & $14 \%$ & 2.18 & $8.10 \%$ & $118 \%$ & 3.22 & $12.40 \%$ & $222 \%$ & 4.26 & $15.60 \%$ & $326 \%$ & 5.30 & $18.15 \%$ & $430 \%$ & 8.40 & 23.728 & $740 \%$ \\
\hline 1.16 & I. $50 \%$ & $16 x$ & 2.20 & $8.20 \%$ & $120 x$ & 3.24 & $12.47 \%$ & $224 \%$ & 4.23 & $15.65 \%$ & $328 \%$ & 5.32 & $18.19 \%$ & $432 \%$ & 8.60 & 24.0180 & $760 \%$ \\
\hline 1.18 & 1.6746 & $18 x$ & 2.22 & $8.30 \%$ & $122 \%$ & 3.26 & $12.54 \%$ & $226 \%$ & 4.30 & $15.70 \%$ & $330 \%$ & 5.34 & $18.24 \%$ & $434 \%$ & 8.80 & $24.29 \%$ & $780 \%$ \\
\hline 1.20 & $1.84 \%$ & $20 \%$ & 2.24 & $8.39 \%$ & $124 \%$ & 3.28 & $12.61 \%$ & $228 \%$ & 4.32 & $15.76 \%$ & $332 \%$ & 5.36 & $18.28 \%$ & $436 \%$ & 9.00 & $24.57 \%$ & $800 \%$ \\
\hline 1.22 & $2.01 \%$ & $22 x$ & 2.26 & $8.50 \%$ & $126 \times$ & 3.30 & $12.68 \%$ & $230 x$ & 4.34 & $15.81 \%$ & $334 \%$ & 5.38 & $18.33 \%$ & $438 \%$ & 9.20 & 24.8596 & $820 \%$ \\
\hline 1.24 & $2.17 \%$ & 2496 & 2.28 & $8.60 \%$ & $128 \%$ & 3.32 & 12.7580 & $2329^{\circ}$ & 4.36 & $15.86 \%$ & $336 \%$ & 5.40 & $18.37 \%$ & $440 \%$ & 9.40 & $25.12 \%$ & $840 \%$ \\
\hline 1.26 & $2.34 \%$ & $26 \%$ & 2.30 & $8.68 \%$ & $130 x$ & 3.34 & $12.82 \%$ & $234 \%$ & 4.38 & 15.928 & $338 \%$ & 5.42 & $18.41 \%$ & $442 \%$ & 9.60 & $25.38 \%$ & $860 \%$ \\
\hline 1.28 & $2.50 \%$ & $28 \%$ & 2.32 & $8.78 \%$ & $132 \%$ & 3.36 & $12.88 \%$ & 23696 & 4.40 & $15.97 \%$ & $340 \%$ & 5.44 & $18.46 \%$ & $444 \%$ & 9.80 & $25.64 \%$ & $880 \%$ \\
\hline 1.30 & $2.66 \%$ & $30 \%$ & 2.34 & $8.87 \%$ & $134 x$ & 3.38 & 12.958 & 23890 & 4.42 & $16.02 \%$ & $342 \%$ & 5.46 & $18.50 \%$ & $446 \%$ & 10.00 & $25.89 \%$ & $900 \%$ \\
\hline 1.32 & $2.82 \%$ & $32 \%$ & 2.36 & $8.97 \%$ & $136 \%$ & 3.40 & $13.02 \%$ & $240 \%$ & 4.44 & $16.07 \%$ & $344 \%$ & 5.48 & $18.54 \%$ & $448 \%$ & 10.20 & $26.14 \%$ & $920 \%$ \\
\hline 1.34 & $2.97 \%$ & $34 \%$ & 2.38 & $9.06 \%$ & 13896 & 3.42 & $13.08 \%$ & 2429 & 4.46 & $16.13 \%$ & $346 \%$ & 5.50 & $18.59 \%$ & $450 \%$ & 10.40 & $26.39 \%$ & $940 \% 6$ \\
\hline 1.36 & $3.12 \%$ & $36 \%$ & 2.40 & $9.15 \%$ & $140 \%$ & 3.44 & $13.15 \%$ & 24496 & 4.48 & $16.18 \%$ & $348 \%$ & 5.52 & $18.63 \%$ & $452 \%$ & 10.60 & $26.63 \%$ & $960 x$ \\
\hline 1.38 & $3.27 \%$ & $38 \%$ & 2.42 & $9.24 \%$ & $142 \%$ & 3.46 & $13.22 \%$ & $246 \%$ & 4.50 & $16.23 \%$ & $350 \%$ & 5.54 & $18.67 \%$ & $454 \%$ & 10.80 & $26.87 \%$ & $980 \%$ \\
\hline 1.40 & $3.42 \%$ & $40 \%$ & 2.44 & $9.33 \%$ & $144 \pi$ & 3.48 & 13.2380 & $248 \%$ & 4.52 & $16.28 \%$ & $352 \%$ & 5.56 & $18.72 \%$ & $456 \%$ & 11.00 & $27.10 \%$ & $1000 \%$ \\
\hline 1.42 & $3.57 \%$ & $42 x$ & 2.46 & $9.42 \%$ & $146 \%$ & 3.50 & $13.35 \%$ & $250 \%$ & 4.54 & $16.33 \%$ & $354 \%$ & 5.58 & $18.76 \%$ & $458 \%$ & 12.00 & $28.21 \%$ & $1100 \%$ \\
\hline 1.44 & $3.71 \%$ & $44 \%$ & 2.48 & $9.51 \%$ & $148 \pi$ & 3.52 & $13.41 \%$ & $252 \%$ & 4.56 & 16.3896 & $356 \%$ & 5.60 & $18.80 \%$ & $460 \%$ & 13.00 & $29.24 \%$ & $1200 \%$ \\
\hline 1.46 & $3.86 \%$ & $46 \%$ & 2.50 & $9.60 \%$ & $150 \%$ & 3.54 & $13.48 \%$ & $254 \%$ & 4.58 & 16.448 & $358 \%$ & 5.62 & $18.84 \%$ & $462 \%$ & 14.00 & $30.20 \%$ & $1300 \%$ \\
\hline 1.48 & $4.00 \%$ & $48 \%$ & 2.52 & $9.68 \%$ & 1528 & 3.56 & $13.54 \%$ & $256 \%$ & 4.60 & $16.49 \%$ & $360 \%$ & 5.64 & $18.89 \%$ & $464 \%$ & 15.00 & $31.10 \%$ & $1400 \%$ \\
\hline 1.50 & $4.14 \%$ & $50 \%$ & 2.54 & $9.77 \%$ & $154 \%$ & 3.58 & $13.60 \%$ & $258 \%$ & 4.62 & $16.54 \%$ & $362 x$ & 5.66 & $18.93 \%$ & $466 \%$ & 16.00 & $31.95 \%$ & $1500 \%$ \\
\hline 1.52 & $4.28 \%$ & 528 & 2.56 & $9.86 \%$ & $156 \%$ & 3.60 & $13.67 \%$ & $260 \%$ & 4.64 & $16.59 \%$ & $364 \%$ & 5.68 & $19.97 \%$ & $468 \%$ & 17.00 & $32.75 \%$ & $1600 \%$ \\
\hline 1.54 & $4.41 \%$ & $54 \%$ & 2.58 & $9.94 \%$ & $158 \%$ & 2.62 & $13.73 \%$ & $262 \%$ & 4.66 & $16.64 \%$ & $366 \%$ & 5.70 & $19.01 \%$ & $470 \%$ & 18.00 & $33.51 \%$ & $1700 \%$ \\
\hline 1.56 & $4.55 \%$ & $56 \%$ & 2.60 & $10.03 \%$ & $160 \%$ & 3.64 & $13.79 \%$ & $264 \%$ & 4.68 & $16.69 \%$ & 36896 & 5.72 & $19.05 \%$ & $472 \%$ & 19.00 & $34.24 \%$ & $1800 \%$ \\
\hline 1.58 & $4.68 \%$ & $58 \%$ & 2.62 & $10.11 \%$ & 1629 & 3.66 & $13.85 \%$ & $266 x$ & 4.70 & $16.74 \%$ & $370 \%$ & 5.74 & $19.09 \%$ & $474 \%$ & 20.00 & $34.93 \%$ & $1900 \%$ \\
\hline 1.60 & $4.81 \%$ & $60 \%$ & 2.64 & $10.19 \%$ & $164 \%$ & 3.68 & $13.92 \%$ & $268 \%$ & 4.72 & $16.79 \%$ & $372 \%$ & 5.76 & $19.14 \%$ & $476 \%$ & 21.00 & $35.59 \%$ & $2000 \%$ \\
\hline 1.62 & $4.94 \%$ & $62 \%$ & 2.66 & $10.28 \%$ & $166 \%$ & 3.70 & $13.98 \%$ & $270 x$ & 4.74 & $16.84 \%$ & 37490 & 5.78 & $19.18 \%$ & $478 \%$ & 22.00 & $36.22 \%$ & $2100 \%$ \\
\hline 1.64 & $5.07 \%$ & $64 \%$ & 2.68 & $10.36 \%$ & $168 \%$ & 3.72 & $14.04 \%$ & 2729 & 4.76 & $16.39 \%$ & $376 \%$ & 5.80 & $19.22 \%$ & $480 \%$ & 23.00 & $36.83 \%$ & $2200 \%$ \\
\hline 1.66 & $5.20 \%$ & $66 \%$ & 2.70 & $10.44 \%$ & $170 \%$ & 3.7 .4 & $14.10 \%$ & $274 \%$ & 4.78 & $16.93 \%$ & $378 \%$ & 5.82 & $19.26 \%$ & $482 \%$ & 24.00 & $37.41 \%$ & $2300 \%$ \\
\hline 1.68 & $5.32 \%$ & $68 \%$ & 2.72 & $10.52 \%$ & $172 \%$ & 3.76 & $14.16 \%$ & $276 \%$ & 4.80 & $16.98 \%$ & $380 \%$ & 5.84 & $19.30 \%$ & $484 \%$ & 25.00 & $37.97 \%$ & $2400 \%$ \\
\hline 1.70 & $5.45 \%$ & $70 \%$ & 2.74 & $10.61 \%$ & $174 \%$ & 3.78 & $14.22 \%$ & $278 \%$ & 4.82 & $17.03 \%$ & $382 \%$ & 5.86 & $19.34 \%$ & $486 \%$ & 26.00 & $38.52 \%$ & $2500 \%$ \\
\hline 1.72 & $5.57 \%$ & $72 x$ & 2.76 & 10.6996 & $176 \%$ & 3.80 & 14.288 & $280 x$ & 4.84 & $17.08 \%$ & $384 \%$ & 5.88 & $19.38 \%$ & $488 \%$ & 27.00 & $39.04 \%$ & $2600 \%$ \\
\hline 1.74 & $5.70 \%$ & $74 \%$ & 2.78 & $10.77 \%$ & $178 \%$ & 3.82 & $14.34 \%$ & 2828 & 4.86 & $17.13 \%$ & $386 \%$ & 5.90 & $19.42 \%$ & $490 \%$ & 28.00 & $39.55 \%$ & $2700 \%$ \\
\hline 1.76 & $5.82 \%$ & $76 \%$ & 2.80 & $10.84 \%$ & $180 \%$ & 3.84 & $14.40 \%$ & $284 \%$ & 4.88 & $17.18 \%$ & 38896 & 5.92 & $19.46 \%$ & $492 \%$ & 29.00 & $40.04 \%$ & $2800 \%$ \\
\hline 1.78 & $5.94 \%$ & $78 \%$ & 2.82 & $10.92 \%$ & $182 \%$ & 3.86 & $14.46 \%$ & $286 \%$ & 4.90 & 17.229 & $390 \%$ & 5.94 & $19.50 \%$ & $494 \%$ & 30.00 & $40.51 \%$ & $2900 \%$ \\
\hline 1.80 & $6.05 \%$ & $80 \%$ & 2.84 & $11.00 \%$ & $184 \%$ & 3.88 & $14.52 \%$ & $288 \%$ & 4.92 & $17.27 \%$ & $392 \%$ & 5.96 & $19.54 \%$ & $496 \%$ & 31.00 & $40.97 \%$ & $3000 \%$ \\
\hline 1.82 & $6.17 \%$ & $82 \%$ & 2.86 & $11.08 \%$ & $186 \%$ & 3.90 & $14.58 \%$ & $290 \%$ & 4.94 & $17.32 \%$ & $394 \%$ & 5.98 & $19.58 \%$ & $498 \%$ & 36.00 & $43.10 \%$ & $3500 \%$ \\
\hline 1.84 & $6.29 \%$ & $84 \%$ & 2.88 & $11.16 \%$ & $188 \%$ & 3.92 & $14.64 \%$ & 2926 & 4.96 & $17.37 \%$ & $396 \%$ & 6.00 & $19.62 \%$ & $500 \%$ & 41.00 & $44.97 \%$ & $4000 \%$ \\
\hline 1.86 & $6.40 \%$ & $86 \%$ & 2.90 & $11.23 \%$ & $190 \%$ & 3.94 & $14.70 \%$ & $294 \%$ & 4.98 & 17.410 & $398 \%$ & 6.10 & $19.82 \%$ & $510 \%$ & 46.00 & $46.65 \%$ & $4500 \%$ \\
\hline 1.88 & $6.52 \%$ & $88 \%$ & 2.92 & $11.31 \%$ & $192 x$ & 3.96 & $14.75 \%$ & $296 \%$ & 5.00 & $17.46 \%$ & $400 \%$ & 6.20 & $20.02 \%$ & $520 \%$ & 51.00 & $48.17 \%$ & $5000 \%$ \\
\hline 1.90 & $6.63 \%$ & $90 \%$ & 0.94 & $11.39 \%$ & $194 \%$ & 3.98 & $14.81 \%$ & $298 \%$ & 5.02 & $17.51 \%$ & $402 \%$ & 6.30 & $20.21 \%$ & $530 \%$ & 61.00 & $50: 85 \%$ & $6000 \%$ \\
\hline 1.92 & $6.74 \%$ & $92 \%$ & 2.96 & $11.46 \%$ & $196 \%$ & 4.00 & $14.87 \%$ & $300 \%$ & 5.04 & $17.56 \%$ & $404 \%$ & 6.40 & $20.40 \%$ & $540 \%$ & 71.00 & $-53.15 \%$ & $7000 \%$ \\
\hline \multirow[t]{3}{*}{1.94} & $6.85 \%$ & $94 \%$ & 2.98 & $11.54 \%$ & $198 \%$ & 4.02 & $14.93 \%$ & $302 x$ & 5.06 & $17.60 \%$ & $406 \%$ & 6.50 & $20.58 \%$ & $550 \%$ & 81.00 & $55.18 \%$ & $8000 \%$ \\
\hline & & & & & & & & & & & & & & & 91.00 & $57.00 \%$ & \\
\hline & & & & & & & & & & & & & & & & & \\
\hline
\end{tabular}

\section{INSTRUCTIONS FOR FINDING DGR}

A. 10 year period: Divide "latest" members by "beginning". Locate the number closest to your answer in column $1 / 1 \mathrm{~s}$. Read both AAGR and DGR.

B. Other than 10 year period:

Step 1: Locate AACR using Table A.

Step 2: On Table B, in AACR column locate AAGR from Table A.

Step 3: Read corresponding DGR.

(see example on page 16):

Note: If exact AAGR number does not appear on Table B, by choosing the closest number you will still be within one percent (1\%) of the exact DCR (up through DCR of 500\%). However, if you want to calculate a more precise DGR, you can make the following calcutation (interpolation).

\section{Finding DCR to the nearest $1 \%$ :}

A. 1/p ro $500 \%$ DCR, increments on Table B are every $2 \%$ DGR. The following example shows you how to obtain DCR to the nearest 1\%:

Example: (say your AAGR is $11.88 \%$ )

Step 1:

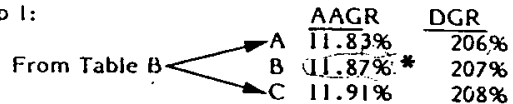

Step 2: $11.87 \%$ is nearest your AAGR of $11.88 \%$ for a DGR of $207 \%$.

* Note: To find $B$, subtract $A$ from $C$, divide answer by 2 , and add this answer to $A$. $\frac{C-A}{2}+A=B$

B. Above 500\%, DGR increments on Table B are $10 \%$ or more.A similar process can be used to determine a more precise DCR.Y ou may need to repeat the above formula 2 or 3 times to narrow the answer down to the nearest $1 \%$. 


\section{BIBLIOGRAPHY}

Allen, Roland. Missionary Methods; St. Paul's and Ours? Grand Rapids: Eerdmans, 1962.

Anderson, Ray S. Theological Foundations for Ministry. Grand Rapids, MI: Eerdmans, 1979.

Barna, George. The Power of Vision. Ventura, CA: Regal Books, 1992 .

Barth, Karl. "The Community for the World." In Theological Foundations for Ministry. ed. Ray S. Anderson. Grand Rapids: Eerdmans, 1979.

Bascom, Maurice. Adult Sabbath School Lessons: Biblical Models of Soul Winning. Silver Spring, MD: Department of Church Ministries, General Conference of SDA, 1994.

Callahan, Kennon L. Effective Church Leadership: Building on the Twelve Keys. New York: Harper \& Row, Publishers, 1990 .

Calvin, John. Institutes of the Christian Religion. 2 vols. London: James Clark Publishing Co., 1959.

Castells, F. de P. "Central America as a Mission Field." Missionary Review of the World 24 (March 1901): 168176 .

"Central America as a Mission Field," Missionary Review of the World 14 (March 1901): 218.

"Central America." General Conference Daily Bulletin 1, no. 3, extra vol. (February 11, 1895): 95-97. 
Chamberlin, Robert $S$. The Conquest and Colonization of Honduras, 1502-1550. 2nd ed. Washington, DC: Carnegie Institution, 1966.

Collins, Sharon. Roatan \& Honduras' Bay Islands. Houston, TX: Pisces Books, 1993.

Curtis, Gilbert D., to Mary P. Elwin, 15 July 1979. Photocopy in my possession.

Dussel, E., R. Cardenal, R. Bendana, J. E. Arellano, M. Carias, M. Picado, and W. Nelson. Historia General de la Iglesia en America Latina. Cehila, Espana: Salamanca, 1985 .

Elwin, Mary P. Handwritten Ms, July 15, 1979, French Harbour SDA Church. Transcription in my possession.

Elwin, Stavely, Governor of Bay Islands, to S. P. Elwin, 27 July 1996.

"Field of Monthly Survey: Central America." Missionary Review of the World 17 (March 1894): 218.

"Fifteenth Meeting, 9:30 A.M., February 23," General Conference Bullentin 8, no. 9 (February 26, 1899): 281.

Floyd, Troy S. The Anglo-Spanish Struggle for Mosquitia. Albuquerque NM: The University of New Mexico Press, 1967 .

Getz, Gene A. Sharpening the Focus of the Church. Chicago: Moody Press, 1974.

George, Carl F. Prepare Your Church for the Future. Grand Rapids: Baker, 1991.

Goddard, Burton L., ed. The Encyclopedia of Modern Christian Missions. London: Thomas Nelson \& Sons, 1967.

Green, Michael. Evangelism in the Early Church. Grand Rapids: Eerdmans, 1970. 
Henrichsen, Walter A. Disciples Are Made Not Born. Wheaton, IL: Tyndale House Publishers, 1988.

Hull, Bill. The Disciple-Making Pastor. Tarrytown, NY:

Fleming H. Revell Co., 1988.

"International Tract Society." General Conference Bulletin

1, no. 7, extra vol. (February 18, 1895): 211.

"International Tract Society Proceedings." General

Conference Bulletin 5, no. 12, (February 20, 1893):

290 .

Jacobson, Susan. The Bay Islands: Nature and People.

Honduras: Paseo Pantera, 1992.

Jowett, J. H. The Preacher: His Life and Work. Grand Rapids, MI: Baker Book House, 1976.

Konopka, Gisela. Social Group Work, a Helping Process.

Englewood Cliffs, NJ: Prentice-Hall, 1963.

Ladd, George. Eldon. A Theology of the New Testament. Grand Rapids: Eerdmans, 1974.

Lefever, Marlene D. Creative Teaching Methods. Elgin, IL:

David C. Cook Publishing Co., 1986.

Lindbergh, Anne Morrow. Gift from the Sea. New York: Random House, 1975.

McGavran, Donald A. The Bridges of God. New York: Friendship Press, 1955.

- Understanding Church Growth. Revised and

edited by C. Peter Wagner. 3rd ed. Grand Rapids, MI: W. B. Eerdmans, 1970 .

McIntosh, Duncan, and Richard E. Rusbuldt E. Planning Growth in Your Church. Valley Forge, PA: Judson Press, 1983.

Mecham, Lloyd J. Church and State in Latin America. Chapel Hill, NC: The University of North Carolina Press, 1966. 
Merrill, Tim L., ed. Honduras: A Country Study. Washington,

DC: Government Printing Office, 1995.

Miskotte, Kornelis. Theological Foundation for Ministry.

Grand Rapids, MI: Eerdmans, 1979.

Mutch, Patricia B. Adventist Youth to Youth. Berrien Springs, MI: Institute for Prevention of Addictions, Andrews University, 1995.

Neufeld, Don F., ed. Seventh-day Adventist Encyclopedia. Rev. ed. Washington, DC: Review and Herald, 1976.

O'Connor, Elizabeth. Call to Commitment. New York: Harper and Row, Publishers, 1975.

Patterson, George, and Richard Schoggins. Church Multiplication Guide. Pasadena, CA: William Carey Library, 1993 .

Pearson, John W., and Robert Hisrich D. Marketing Your Ministry. Brentwood, TN: Wolgemuth and Hyatt, 1990.

Peters, George W. A Theology of Church Growth. Grand Rapids: Zondervan, 1981 .

Powell, John. Unconditional Love. Niles, IL: Arguq Communications, 1978.

- Why Am I Afraid to Love? Allen, TX: Argus Communications, 1967.

Powell, Robert K. Managing Church Business Through Group Procedures. Englewood Cliffs, NJ: Prentice-Hall, 1964.

"Report of Educational Secretary." General Conference Bulletin 1, no. 8, extra vol. (February 19, 1895): 222.

"Report of the Central American Conference," General Conference Daily Bulletin 6, no. 20 (June 6, 1909): 338 . 
Richards, Lawrence 0 . Christian Education Grand Rapids, MI: Zondervan Publishing House, 1975.

Roark, Dallas M. Makers of the Modern Theological Mind: Dietrich Bonhoeffer. Edited by Bob E. Patterson. Waco, TX: Word Books, 1976 .

Rose, Richard H. Utilla: Past and Present. Dansville, NY: F. A. Owen Publishing Company, 1904.

Smalley, William A., ed. Readings in Missionary Anthropology II. South Pasadena, CA: William Carey Library, 1978.

Torrence, James B. "The Place of Jesus Christ in Worship." In Theological Foundation for Ministry, ed. Ray S. Anderson. Grand Rapids: Eerdmans, 1979.

Tournier, Paul. A Place for You. New York: Harper \& Row Publishers, 1968.

Treaty Between Her Majesty and the Republic of Honduras, Respecting the Bay Islands, the Mosquito Indians, and the Rights and Claims of British Subjects. Comayaqua, November 28, 1859. London: Harrison and Sons, 1860.

Verkuyl, J. Contemporary Missiology. Translated by Dale Cooper. Grand Rapids: Eerdmans, 1978.

Wagner, Peter C. Church Planting for a Greater Harvest. Ventura, CA: Gospel Light Publications, 1990. - Strategies for Church Growth. Ventura, CA: Gospel Light Publications, 1976.

Warren, Caroline. Utilla, to Drusilla Borden, Roatan, 24 June, 1941.

Werning, waldo J. "Biblical Church Growth." Globas (JanuaryMarch 1994): 3 .

"West Indies and Central America." General Conference Daily Bulletin 5, no. 11 (February 17, 1893): 281. 
White, Ellen G. Evangelism. Washington, DC: Review and Herald Pub. Assoc., 1946.

Winn, Wilkins B. Pioneer Protestant Missionaries in Honduras. Cuernavaca, Mexico: Cidox Dossier, 1973. 